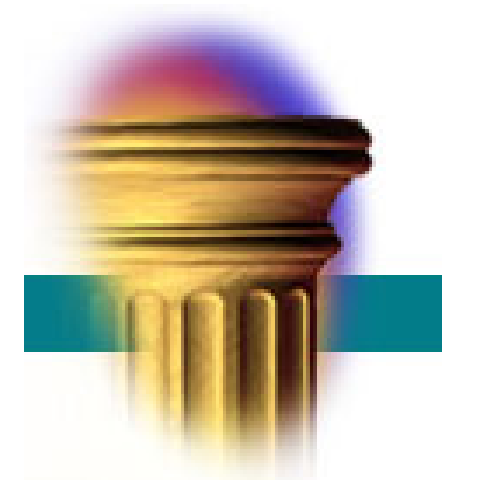

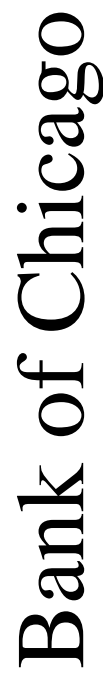

The Earned Income Tax Credit and Food Consumption Patterns

Leslie McGranahan and Diane W. Schanzenbach

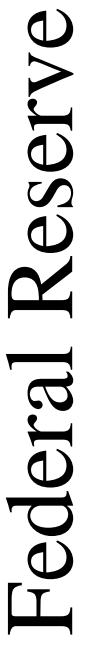

November 2013

WP 2013-14 


\title{
The Earned Income Tax Credit and Food Consumption Patterns
}

\author{
November 20, 2013 \\ Leslie McGranahan \\ Federal Reserve Bank of \\ Chicago \\ Diane W. Schanzenbach \\ Northwestern University \\ and NBER
}

\begin{abstract}
The Earned Income Tax Credit is unique among social programs in that benefits are not paid out evenly across the calendar year. We exploit this feature of the EITC to investigate how the credit influences the food expenditure patterns of eligible households. We find that eligible households spend relatively more on healthy items including fresh fruit and vegetables, meat and poultry, and dairy products during the months when most refunds are paid.

JEL Codes: H3 (Fiscal Policies and Behavior of Economic Agents), I38 (Government Policy; Provision and Effects of Welfare Programs), Q18 (Agricultural Policy; Food Policy)

Keywords: Earned Income Tax Credit, Obesity, Healthy Eating, Food Expenditures
\end{abstract}

The opinions expressed in this paper are those of the authors and do not reflect the opinions of the Federal Reserve Bank of Chicago or the Federal Reserve System. 


\section{Introduction}

The Earned Income Tax Credit (EITC) began in 1975 as a small program designed to offset payroll taxes among low income working families with children. Over the subsequent four decades it has grown into one of the largest means tested Federal programs. For Tax Year 2011, the Federal government spent $\$ 63$ Billion on the EITC rendering it the largest Federal cash assistance program and the second largest non-health means tested program, after the Supplemental Nutrition Assistance Program (SNAP) (IRS, 2013; CBO, 2013). The growth of the EITC has been the result of numerous policy expansions which have both broadened the coverage of the program and dramatically increased benefit levels among recipient families.

The EITC is structured as a subsidy to work among targeted families. Households receive a benefit that equals a percentage of earnings up to a maximum credit amount. Households with earnings along a plateau range also receive this maximum credit. Higher income households gradually see their credit phase-out as earnings increase until the entire credit is phased out. This complex structure has led researchers to investigate the labor supply effects of the EITC. Most academic research on the EITC has highlighted the EITCs positive labor supply effects especially among single mothers. The EITC has served to increase work participation among targeted households without reducing the labor supply of working households. (For a summary see Hoynes and Eissa 2006).

A smaller body of research has investigated the effects of the EITC on household consumption patterns. This research has highlighted the increase in work related expenditures among recipient households (Patel 2011); a result consistent with the program's large labor supply effects. Other research has exploited the lump-sum nature of payments to investigate changes in spending around the timing of benefit receipt (Barrow and McGranahan 2000; Goodman-Bacon and McGranahan 2008). Most EITC recipients have received their benefits in the form of a lump sum payment that is part of the household's tax refund. Recipients had been permitted to receive some benefit payments in the calendar year prior to tax filing via Advance EITC payments. However, due to minimal take-up of these payments, the Advance EITC was repealed and no longer available after 2010. Previous research focused on the timing of EITC receipt has found increases in spending on durables, especially cars, in response to the large lump sum transfer. We exploit the lump-sum nature of EITC payments to investigate how food spending among EITC recipients changes in the period of EITC receipt. In particular, we investigate spending patterns in those months when most EITC benefits are received. 
The focus of the paper is spending on food. We are interested in both overall food spending and on its composition across food categories. According to the National Health and Nutrition Expenditure Survey (NHANES), obesity is higher among the groups targeted by the EITC than other groups. In particular, women with incomes below $130 \%$ of the poverty line have obesity rates 13 percentage points higher than women with incomes above 350\% of the poverty line (Ogden et al 2010A) while lower income boys have obesity rates that are 10 percentage points higher and lower income girls have obesity rates that are 7 percentage points higher (Ogden et al 2010B). Our analysis is informative about the link between income and food consumption patterns. We are able to ask whether there are changes in the spending patterns of EITC households during a period of the year when their income is likely to be the highest.

Because of the link between socioeconomic status and obesity, a number of policy interventions have sought to influence the food choices of low-income households. In particular, interventions have sought to decrease the relative price and increase the availability of healthy foods. A growing body of work has analyzed these interventions. One recent intervention, the Healthy Incentives Pilot (HIP), was found to increase spending on fruits and vegetables among families that received a SNAP bonus for money spent on fruits and vegetables (Bartlett et al. 2013). Our results are consistent with this finding in that we observe that households make healthier food choices when they have more income.

In the current paper we use data from the Consumer Expenditure Diary Survey (Diary) to ask how household food expenditure pattern change in the months when EITC benefits are received. In the future, we hope to expand our analysis to include data from the NHANES and investigate food consumption. We find that households receiving EITC benefits spend more on healthy foods and protein in EITC months. We interpret these finds as telling us both how individuals spend their EITC refunds and how low income household food choices respond to an increase in income.

\section{Background on the EITC and Benefit Timing}

As noted earlier, the generosity of the EITC has evolved over time. However, its basic structure has remained unchanged with an earning subsidy, a plateau range, and a phase out range. In Figure 1, we display a graph of the program parameters (as constructed by the Center for Budget and Policy Priorities 2013) for 2012. As is shown in the Figure, there is a small benefit for childless households and benefit schedules that increase in generosity for families with more children. In Figure 2, we graph the (nominal) level of maximum benefits over time by family size. Through 1990, families with children faced the same schedule independent of their size. From 1991 on, families with two or more children 
received a higher benefit. Starting in 2009, families with three or more children received even higher benefits. A small benefit for households without children was added in 1994.

The growing generosity of the program led to growing costs. Figure 3 graphs spending on all Federal means tested programs (CBO 2013). Tax Credits (including the EITC and the much smaller Child Tax Credit) have grown from a small portion of the safety net, to a major component of it.

Throughout its history, the EITC has been a refundable tax credit that has been part of the tax code. It has been paid out along with filers' tax refunds and has been fully refundable - credits in excess of tax liability are paid out as refunds. Through 2010, filers could receive some EITC dollars in the form of the Advance EITC, but this program was discontinued because it was characterized by high errors and minimal take up.

Individuals who are expecting a fixed nominal benefit from the government have an incentive to file their taxes and receive their refunds as early as possible. While many high income people wait until the tax filing deadline on April $15^{\text {th }}$ to file their taxes, EITC recipients tend to file early. In order to file taxes an individual needs to have his W2 form and the IRS filing window needs to be open. Employers are required by the Federal government to issue $\mathrm{W}-2 \mathrm{~s}$ by January 31 and the tax window opens in midJanuary. In 2011, the window opened on January $14 .^{1}$ The 2012 window opened on January 17 and in 2013 it opened on January 30. The day the window opens tends to be the first day that volunteer sites open and is the first date that paid preparers can submit returns. ${ }^{2}$

Once the return is submitted, the IRS processes it and sends out refunds. According to the IRS, under normal processing, refunds for e-filed returns are direct deposited two Fridays after the return is filed and paper checks are mailed three Fridays after filing. Refunds from paper returns take longer approximately six to eight weeks. In 2010, sixty-nine percent of returns were filed electronically and sixty-eight percent of refunds were direct deposited. These percentages have been increasing over time and as a result payments have been being received progressively earlier.

In Figure 4, we display the percent of EITC refunds paid out by the IRS by month from selected years in our sample period, 1982, 1992, 2002 and 2012 based on data from the US Treasury's Monthly

\footnotetext{
${ }^{1}$ In 2011, individuals with itemized deductions and some others needed to wait until mid-February to file 2010 taxes. This was due to late in year tax changes to extend the Bush tax cuts.

${ }^{2}$ This is also the first day that Refund Anticipation Loans could be issued because they were issued when returns were filed.
} 
Treasury Statement (MTS). These are refunds in excess of tax liability. Over $90 \%$ of the value of the EITC is delivered in the form of tax refunds, as opposed to serving to reduce tax liabilities. Over this 20 year time period, the pattern of EITC refunds has been fairly consistent. Payments have been sent out at the beginning of the year. In the earliest years of the sample, the modal month was March, with large payments in April and May and a smaller amount in February. In most recent years, the majority of benefits have been paid by the IRS in February, another sizeable amount in March, modest amounts in January and April and very few the remainder of the year. ${ }^{3}$ In Figure 5, we display the average month of payments over the entire sample period (1982-2012). This demonstrates both that payments have been getting earlier and that they occur very early in the year. In Figure 6, we compare the monthly pattern for EITC refunds for 2012 to the pattern for overpayment refunds and the benefits of other income support programs. The patterns for these other programs are quite different from the pattern for the EITC. Temporary Assistance to Needy Families (TANF) and SNAP benefit payments are nearly constant across the months of the year. Overpayment refunds are sent out in February, March and April with a sizeable amount in May as well. Child Nutrition payments drop during the summer months but are fairly constant during the school year.

The lump sum EITC payment is large when taken in the context of the incomes of targeted households. The IRS reports that 28 million people filed EITC returns for tax year 2011 (refunds received in early 2012 (IRS 2013). The average refundable credit was $\$ 1,983$. The average ranged from $\$ 188$ for families with no kids to $\$ 3,342$ for families with three kids or more. These amounts represent $3 \%$ of the AGI of the average recipient household without kids of $\$ 6,763$ and $14 \%$ of the average $A G I$ of a recipient family of $\$ 24,198$ with three kids or more (IRS 2013). If we assume that a household receives an amount equal to $1 / 12^{\text {th }}$ of its $A G I$ in the month it receives the EITC, in that month, the income of the average household increased by $39 \%$ for the household without kids and by $163 \%$ for the households with three kids. These increases are even more dramatic in the more generous ranges of the EITC. A household with three kids earning $\$ 12,780$ a year would receive an EITC of $\$ 5,751$ which would increase its monthly income five-fold. The EITC program pays out a substantial sum of money to a specific group of households over a very narrow window of time.

\section{Data}

\footnotetext{
${ }^{3} 2004$ is an exemption to this pattern. This difference from other years was only seen for EITC payments and not for other refunds. It may be due to some additional efforts to reduce EITC noncompliance.
} 
We use data from the Diary portion of the Consumer Expenditure Survey (CEX) from 1982-2011 to investigate the expenditure response to the EITC. The unit of analysis in the CEX is the "Consumer Unit (CU)" which is conceptually similar to a "household" and we use these terms interchangeably. The data contain information on the weekly spending of household based on entries in spending diaries. Households are asked to detail the food (and other) items they purchased independent of the means of payment. Importantly for our analysis, items purchased with Food Stamps are treated the same as items paid for in other ways. ${ }^{4}$ We do not have data on prices and quantities separately, but only on expenditures. Each diary covers spending for one week. Households are in the sample for two consecutive weeks. The Dairy is intended to cover spending on frequently purchased items such as groceries. By comparison, the better known CEX Interview Survey focuses more on big ticket items. In keeping with this distinction, in the creation of weights for the Consumer Price Index, the Bureau of Labor Statistics uses the Diary data to measure consumption for nearly all food and beverage spending categories. The microdata contain spending information on food at home and food away from home in aggregate as well as for fairly detailed subcategories. For example, in addition to data on weekly household spending on fresh fruit, we also have separate data on spending on apples, bananas, and oranges.

The data also contain information on the socio-demographics of the household, measures of household income, and limited data on social program receipt. There are a number of questions concerning SNAP receipt, but there is no data on EITC receipt.

Following Barrow and McGranahan (2000), we combine individuals within the CU to create tax units and impute EITC based on the earned income of the individuals in these tax units, tax unit composition and the EITC schedule. The income data in the Diary is not tax year income, but rather income in the twelve months leading up to the survey date. We assume that this income is equal to the income in the previous tax year and impute EITC based on that. For example, a household with three children observed in June 2004 that reports $\$ 20,000$ of income is assumed to have made $\$ 20,000$ in tax year 2003 and been eligible for an EITC benefit of $\$ 2,884$ based on the 2003 tax schedule. They are imputed as EITC eligible in June 2004. Their refund would have been received when 2003 taxes were filed in early 2004.

\footnotetext{
${ }^{4}$ The instructions specifically say to include payments by "Food Stamps" and "WIC Voucher." BLS 2013.
} 
There is a change in the treatment of income during out sample period. In particular, income imputation began in 2004. As a result, reasonable income values are provided for all households at this point, not just those deemed to be complete income reporters. We restrict our sample to complete income reporters prior to 2004, but include all households in later years. In Appendix A, we discuss how well our EITC imputation procedure works by comparing data from our CEX based imputation to data from the IRS.

In Table 1, we display variable means from our sample, both for the overall population and by imputed EITC eligibility. Observations are at the Consumer Unit-by-week level, and we restrict the sample to households headed by individuals aged 18-65. In the first panel of the Table, we display means of weekly food spending. We break food into food at home and food away from home and further divide these into a series of categories. We also add three special categories at the bottom of the table that may be of interest to policy makers - sugar sweetened beverages, junk food and healthy food. The contents of these categories are displayed in Table 2. The average consumer unit spends $\$ 130$ per week -- $\$ 80$ of this on food consumed at home and $\$ 50$ on food consumed away from home. When we compare by imputed EITC eligibility, we note that EITC households spend less on average. They spend a similar amount on food at home and a far lower amount on meals away from home - in particular at full service restaurants.

Panel B of Table 1 shows means of the socio-demographic variables. EITC households are larger on average, contain more children, are more likely to be less educated and female headed, and are far lower income. All of these are consistent with a program that is designed to help low income families with young children. In the sample, $15 \%$ of households are imputed to be EITC eligible. This ranges from 7 percent in the early years of the sample and increases to over $20 \%$ in the most recent years. The average EITC benefit is over $\$ 1500$, or about 2.5 times average weekly income among recipients. By comparison, the average recipient is imputed to receive about $\$ 70$ from state EITC programs. ${ }^{5}$ Many recipients also report receiving Food Stamps. However, other studies (see for example Meyer, Mok and Sullivan 2008, and Hoynes, McGranahan and Schanzenbach 2013) indicate that Food Stamp receipt is severely underreported in the CEX data.

3. Results and Methodology

\footnotetext{
${ }^{5}$ We only impute state EITC receipt for those individuals where the state code is not suppressed in the microdata.
} 
To investigate the impact of the EITC on food spending, we begin by estimating the determinants of food spending in general. We estimate:

$$
E_{i t}=\alpha+\beta X_{i}+\gamma E I T C_{i}+M_{t}+Y_{t}+\varepsilon_{i t}
$$

Where $E_{i t}$ is expenditure by CU $i$ at time t. $X_{i}$ is a series of socio-demographic characteristics assumed to affect food spending, $E I T C_{i}$ is a dummy equal to 1 if the $\mathrm{CU}$ is imputed to be EITC eligible, $M_{t}$ is a series of monthly dummies designed to capture the monthly seasonality in food consumption and prices which is assumed to be constant across years. For example, this will capture high candy spending in October. $Y_{t}$ is a series of year dummies which capture changing aggregate prices, consumer preferences and survey categorization. $\varepsilon_{i t}$ is an error term.

The results for estimating equation 1 via OLS for seventeen different categories of food spending are presented in Table 3. Each column in the table displays the result for a different regression. Spending on all seventeen categories is increasing in family size and income. Spending is lower for families with more children in most categories in keeping with their lower caloric needs. The exceptions to this pattern are cereal and bakery products, dairy products, sweets and junk food. We also find that spending is higher across all categories in the first interview. This is likely a sign of interview fatigue where the respondent enthusiasm wanes in the second diary week. Male headed households spend less on food at home and more on food away from home. Households imputed to be EITC eligible generally consume less across most categories even controlling for these other covariates.

Having established overall expenditure patterns, we now turn to whether these expenditure patterns change differentially among EITC households in those months when households are likely to receive their EITC. We first do this by adding to Equation 1 a series of interactions between the EITC dummy and the month dummies. In particular, we estimate

$$
E_{i t}=\alpha+\beta X_{i}+\gamma E I T C_{i}+\lambda E I T C_{i} \times M_{t}+M_{t}+Y_{t}+\varepsilon_{i t}
$$

Where $\lambda$ is a vector of month-specific expenditure responses for EITC eligible households. This tells us whether the monthly spending pattern of EITC households differs from the pattern of other households. We display coefficient estimates for the EITC dummy and the EITC month interactions in Table 4. We omit the September interaction. As a result these effects are relative to spending among EITC 
households in September. In the bottom two rows of the tables, we show the average of the February and March coefficients and a test of whether these coefficients are jointly different from zero. We look at these two months, because most benefits have been received in those months according to the MTS data. $^{6}$

For overall food spending (column 1), we find that food spending is relatively lower for EITC households in most months than it is in September - most of the coefficients are negative. The two largest coefficients are in February and March, but we can't reject that the February and March marginal EITC effects are equal to zero. The results differ across the different food categories. There are only five food expenditure categories for which the results in February and March are jointly different from zero. We observe significantly higher spending on meat, poultry, fish and eggs, dairy, fresh fruit and vegetables, and healthy food. We see lower spending on processed fruit and vegetables.

There are a couple of limitations to this methodology. First, the fact that it compares spending to September may or may not be appropriate. Additionally, it only looks at February and March and treats them the same. However, in the early years of the EITC most benefits were paid out in March, while in more recent years most benefits have been paid in February. We next propose a methodology that addresses these issues. We calculate a variable share_EITC which measures the share of annual EITC benefits paid out in a given month and year. For example, this variable would take on the value 0.59 in February 2006 because fifty-nine percent of 2006 benefits were paid out in February according to the MTS. By contrast it takes on the value 0.17 in February 1982 because seventeen percent of 1982 benefits were paid out in February. We replace the month-EITC interaction with the measure of the share of annual benefits paid out in a given month interacted with the EITC dummy. Our new equation is:

$$
E_{i t}=\alpha+\beta X_{i}+\gamma E I T C_{i}+\chi \text { share }_{-} \text {EITC }_{t} \times E_{\text {ITC }}+M_{t}+Y_{t}+\varepsilon_{i t} \quad \text { (Equation 3) }
$$

The coefficient $\chi$ measures whether EITC eligible households spend relatively more in months when more EITC is paid out - controlling for other covariates, the different demand of EITC households, yearly

\footnotetext{
${ }^{6}$ Two factors push the benefits earlier than is captured by the MTS data. First the MTS data only measure the refundable portion. About $10 \%$ of EITC benefits are in the form of reduced tax liability. Presumably this type of benefit is received when taxes are filed. Second, recipients may expedite receipt of funds via Refund Anticipation Loans (RALs). These tend to be one to two week loans that allow recipients to receive funds when taxes are filed. According to Wu (2012) 18\% of EITC recipients received RALs in 2010. RALs are no longer legal (as of April 2012). Their replacement, Refund Anticipation Checks (RACs), do not expedite fund availability.
} 
trends and monthly seasonality. The results are presented in Table 5. The coefficient 12.64 in the second row of column one can be interpreted that if $100 \%$ of EITC benefits were paid in a given month, we would expect EITC households to spend an additional \$12.64 on food in each week of that month. We don't see negative coefficients for any of the share-EITC interactions for any of the categories and see statistically significant increases in food, food at home, meat, poultry, fish and eggs, dairy, fresh fruit and vegetables, food away from home, fast food and healthy foods. In the bottom two rows of the table, we add two calculated statistics. First, we calculate the percent increase in spending in each food category by dividing the coefficient on the EITC-share interaction by average weekly food spending. A \$12.64 increase in spending would represent a 9.7\% increase in average household spending on food. The largest percentage increases are in meat, poultry, fish and eggs, dairy and healthy food. The smallest increases are in fats and oils and sugar sweetened beverages. Second, in the final row of the table we calculate the percent of average EITC benefits that would be spent on that food in a month with a $100 \%$ share of EITC payments. To do this, we multiply the coefficient by 4.3 to translate the weekly additional spending into monthly additional spending and divide this by the average imputed benefit among those eligible. We find that about 3.5\% of the average total benefit would be spent on food.

Thus far in the analysis, we have not distinguished between different types of recipient households such as those who are imputed to receive low benefit amounts and those imputed to receive larger benefits. To some degree this is by design because the imputation procedure is bound to be imprecise in the face of imperfect income data, and differences in the timing of reported income (prior 12 months) and EITC period (prior calendar year). To investigate what role benefit amount and other attributes play, we rerun the analysis for a series of population groups. We perform this analysis for a subset of the 17 food spending categories. We choose to look at total food spending, food at home, fresh fruits and vegetables, food away from home, healthy food and junk foods.

In Table 6, we display estimates of the coefficient on the interaction between the month EITC share and the EITC dummy for different population subsets for the smaller set of spending categories. Below each coefficient estimate we display the percentage increase in weekly spending in that food category among that population would be estimated to occur if $100 \%$ of benefits were received in a month and the additional percent of average EITC benefits among households in that subpopulation we estimate would be spent on that category of food. In the first column, we repeat the results for the full sample. In columns (2)-(4) we compare to other households that have characteristics typical of the 
eligible. We find smaller and insignificant increases in total food spending among EITC households when compared to other households with kids and households with a less educated head. We continue to find large increases in healthy food spending for these two groups. When we compare EITC households to other low income households, we continue to find increases in consumption across the same set of expenditure categories that we did for the full sample. Our results also hold in columns (6)-(9) when we drop those households from the analysis that we either impute to receive the small EITC for childless families or are imputed to receive a small EITC. In columns (9) and (10) we divide the sample into first and second interview households. Our results are much stronger for first interview households. We find that total food spending increases by $16 \%$ and $6 \%$ of the average benefit was spent on food. Looking across the food subcategories we find a $21 \%$ increase in healthy food spending and an $18 \%$ increase in spending on fruits and vegetables in first interview weeks. We believe that the data provided in the first interview is more accurate. In columns (11) and (12), we divide the sample into male and female headed households. The results are broadly similar across the two household types. Across all 12 specifications, we find increased spending on healthy foods. We find significant increases in spending on junk foods in none of the specifications.

In Table 7, we show results dividing the households into three groups based on the year of the diary. Our year groupings are designed to capture different periods in the life of the program. The first period is 1982-1987 (tax years 1981-1986). We view this as part of the early low benefit period of the program. During this period, the average imputed real benefit was $\$ 600$. The second period is 1988 1994 where benefits averaged $\$ 1089$. We view this as the period of program expansion when the benefits were increasing dramatically during many years. The final period is 1996 and after where benefits averaged $\$ 1806$. We view this as the stable high benefit period. For the early period, we see no increases in food spending. In the second period, we see large increases in spending. Total food spending is estimated to grow $16 \%$ in a month when $100 \%$ of benefits are paid. In the final period, we see modest increases in spending. We see the largest increase in spending in the middle period when benefits were growing the most rapidly, rather than in the last period when the benefits were the highest. As a robustness check, we perform the same analysis for just the first household interview and present the results in Table 8. We see a similar pattern with the largest spending increases in the middle years. However, in this case we see increases in spending across all three time periods (although not statistically significant in the earliest period). Some of the percentage increases in this case are quite large with a 42\% increase in spending on fresh produce between 1988 -1994 and increases in healthy food spending ranging from $15 \%$ to $46 \%$. 
There are two potential explanations for observing the largest increases in the middle period. First, this period is characterized by dramatic increases in benefits. This may mean that EITC households were positively surprised when they found out their refund amount. Households may spend these surprise benefits differently from anticipated benefits. As a second explanation, in the years after 1994, the magnitude of the benefits may lead households to spend more of their money on big ticket items. The large benefit checks may go directly to large durables rather than to food. We could partly clarify these stories if we could look at spending responses in these different time periods in the interview data where spending on large consumer durables is captured.

\section{Conclusion}

Using the Diary data from the Consumer Expenditure Survey, we have investigated whether households imputed to be EITC eligible spend more on food and make different food choices in those months when most EITC benefits are received.

We find that eligible households do spend more on food, and particularly on healthy foods in those months when most benefits are paid. These effects are stronger in the first Diary interview when data collection is likely to be more accurate (Cantor et al. 2013) and in the middle years of our sample. Our results are robust across a number of subpopulations.

These findings are consistent with a growing literature that shows that low-income individuals make better food choices when they are less constrained. Low income individuals eat healthier food when it is more accessible. Recent interventions have shown that households purchase more healthy food when it is more readily available or when it is relatively cheaper. We add to this discussion by finding that they also purchase more healthy foods when they have more income. This finding also suggests that decreases in resources, as occurred recently through the reduction in SNAP benefits, may have the effect of reducing the diet quality of low income families. 


\section{References}

Barrow, Lisa and Leslie McGranahan, 2000. "'The Effects of the Earned Income Credit on the Seasonality of Household Expenditures" National Tax Journal 53(4) (part 2): 1211-1244.

Bartlett et al. U.S. Department of Agriculture, Food and Nutrition Service, Office of Research and Analysis, "Healthy Incentives Pilot (HIP) Interim Report," Project

Officer: Danielle Berman, Alexandria, VA: July 2013.

Bureau of Labor Statistics (BLS). 2013. "Dairy Survey Form."Available on the Internet at: http://www.bls.gov/cex/csx801 2013.pdf.

Bureau of Labor Statistics. Various Years. Consumer Expenditure Survey: Diary Survey.

Cantor, David, Nancy Mathiowetz, Sid Schneider and Brad Edwards. 2013 "Redesign Options for the Consumer Expenditure Survey," Report prepared by Westat for the Bureau of Labor Statistics, June 21, 2013. Available on the Internet at http://www.bls.gov/cex/ce gem west redesign.pdf.

Center for Budget and Policy Priorities, 2013, "Policy Basics: The Earned Income Tax Credit," February 1, 2013. Available on the Internet at: http://www.cbpp.org/cms/?fa=view\&id=2505

Congressional Budget Office, "Growth in Means-Tested Programs and Tax Credits for Low-Income Households." February 11, 2013. Available on the web at http://www.cbo.gov/publication/43934.

Eissa, Nada \& Hilary W. Hoynes, 2006. "Behavioral Responses to Taxes: Lessons from the EITC and Labor Supply," NBER Chapters, in: Tax Policy and the Economy, Volume 20, pages 73-110 National Bureau of Economic Research, Inc.

Goodman-Bacon, Andrew and Leslie McGranahan. 2008. "How Do EITC Recipients Spend their Refunds?" Economic Perspectives, Vol 32, $2^{\text {nd }}$ Quarter.

Internal Revenue Service (IRS). 2011. "2011 IRS E-File Refund Cycle Chart" http://www.irs.gov/pub/irspdf/p2043.pdf.

Internal Revenue Service. 2013. SOI Tax Stats - Individual Income Tax Returns Publication 1304

(Complete Report), 2013. Available on the Internet at http://www.irs.gov/uac/SOl-Tax-Stats-IndividualIncome-Tax-Returns-Publication-1304-(Complete-Report)

Internal Revenue Service. Various Years. Statistics of Income. Available on the Internet at http://www.irs.gov/uac/SOI-Tax-Stats-Archive---1954-to-1999-Individual-Income-Tax-Return-Reports.

Meyer, Bruce D, Wallace K.C. Mok and James X. Sullivan. 2009. "The Under-Reporting of Transfers in Household Surveys: Its Nature and Consequences." NBER Working Papers 15181.

National Bureau of Economic Research. 2013. "State Earned Income Credits in TAXSIM." Available on the Internet at http://users.nber.org/ taxsim/state-eitc.html. 
Ogden Cynthia L, Lamb Molly M, Carroll Margaret D, Katherine M. Flegal. Obesity and socioeconomic status in adults: United States 2005-2008. NCHS data brief no 50. Hyattsville, MD: National Center for Health Statistics. 2010A. Available on the Internet at http://www.cdc.gov/nchs/data/databriefs/db50.pdf

Ogden, Cynthia L, Molly M. Lamb, Margaret D. Carroll Obesity and socioeconomic status in children and Adolescents: United States 1988-1994 and 2005-2008. NCHS data brief no 51. Hyattsville, MD: National Center for Health Statistics. 2010B. Available on the Internet at http://www.cdc.gov/nchs/data/databriefs/db51.pdf

Patel, Ankur. 2011. "The Earned Income Tax Credit and Expenditures," mimeo University of California Davis.

Tax Policy Center, “Earned Income Tax Credit Parameters: 1975-2013," January 28, 2013. Available on the Internet at: http://www.taxpolicycenter.org/taxfacts/Content/PDF/historical eitc parameters.pdf.

United States Department of the Treasury, Financial Management Service. Various Issues, "Monthly Treasury Statement."

Wu, Chi Chi, "The Party's Over for Quickie Tax Loans: But Traps Remain for Unwary Taxpayers," February 2012. National Consumer Law Center and Consumer Federation of America. Available on the Internet at http://www.nclc.org/images/pdf/pr-reports/report-ral-2012.pdf 
Figure 1: EITC Program Parameters, 2012

\section{Value of Federal Earned Income Tax Credit, 2012}

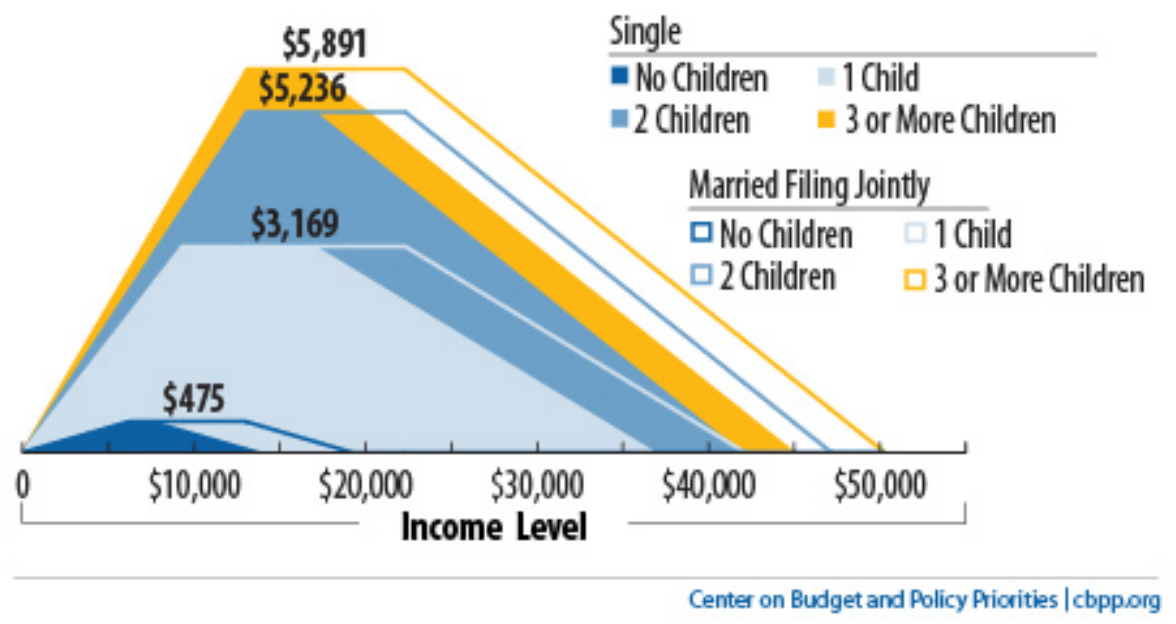

Note: Copied with permission from the Center for Budget and Policy Priorities (2013).

Figure 2: Maximum Benefits by Number of Children

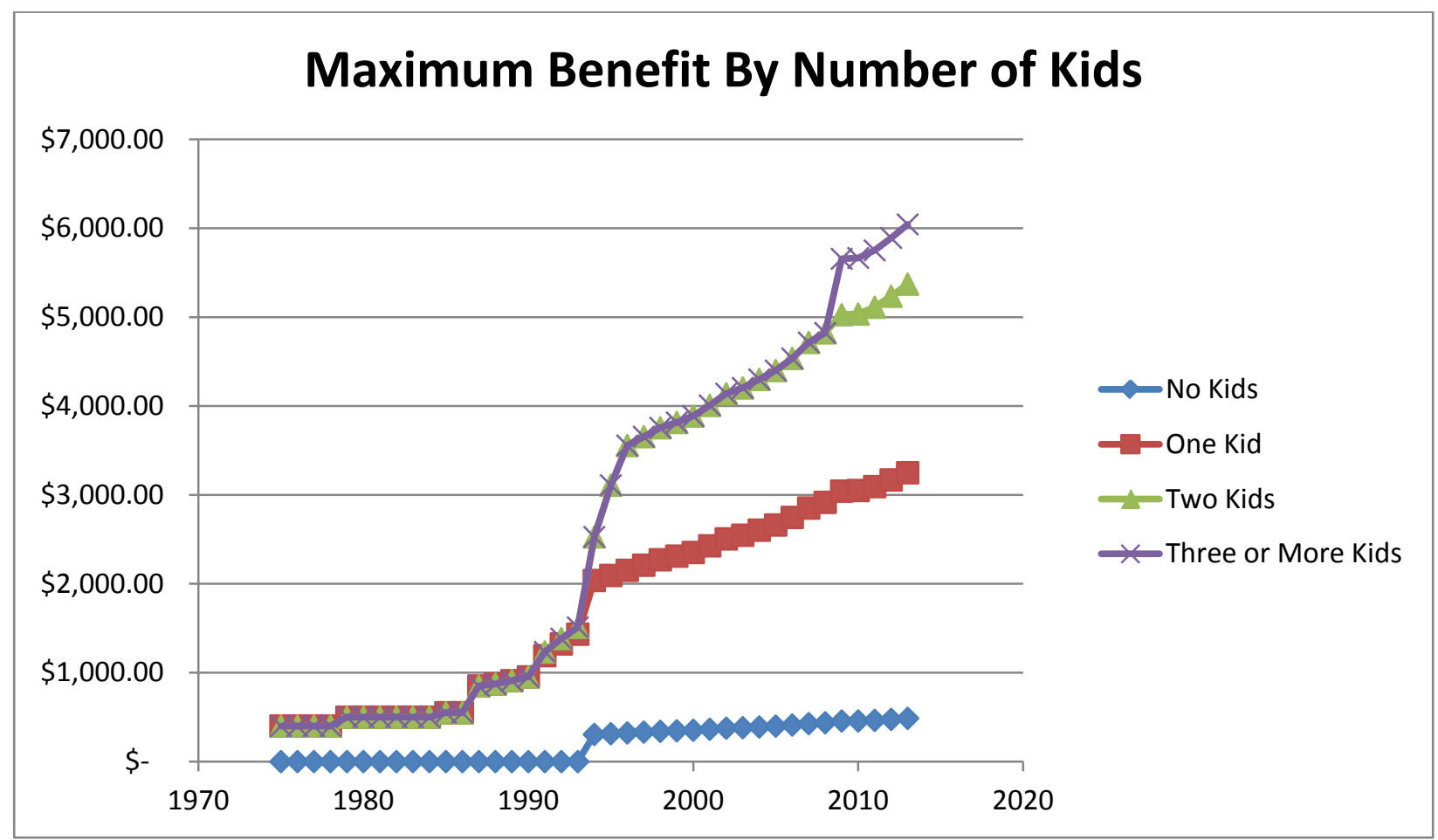

Source: Author's Tabulations from Tax Policy Center (2013). Amounts in Current Dollars. 
Figure 3: Spending on Federal Means Tested Programs Time

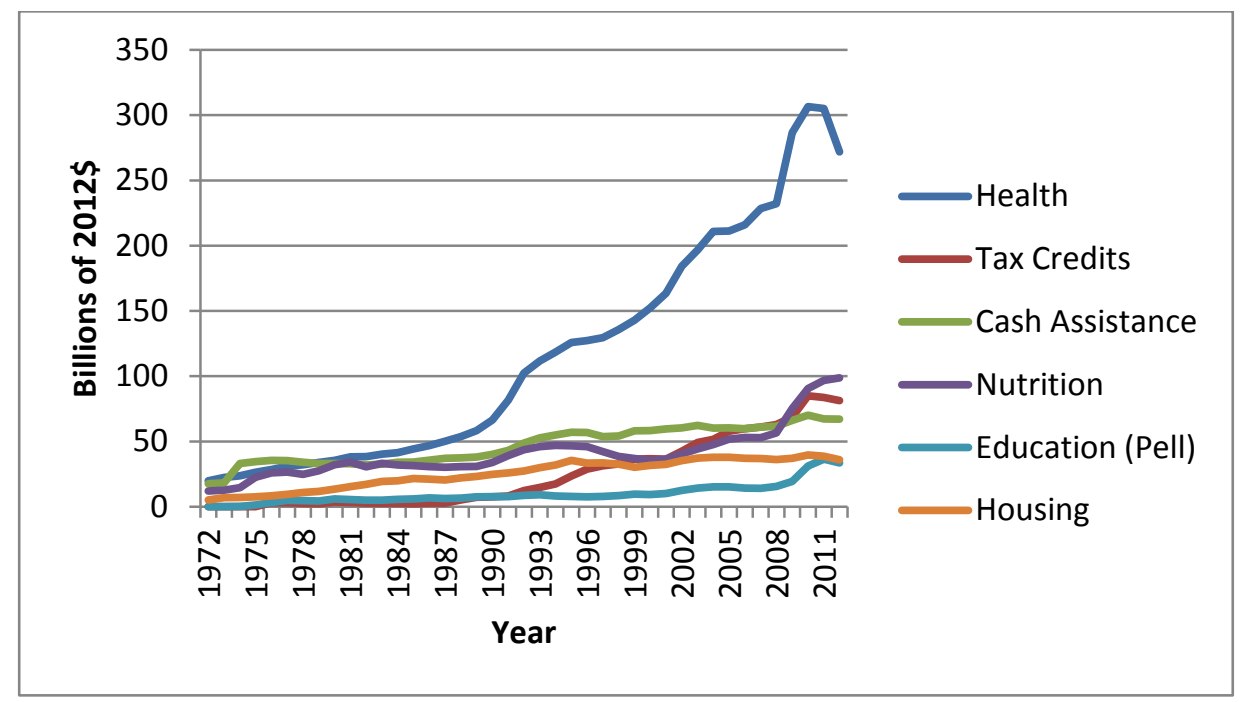

Source: Congressional Budget Office, Growth in Means-Tested Programs and Tax Credits for LowIncome Households, February 11, 2013.

Figure 4: Monthly Shares of EITC Payments

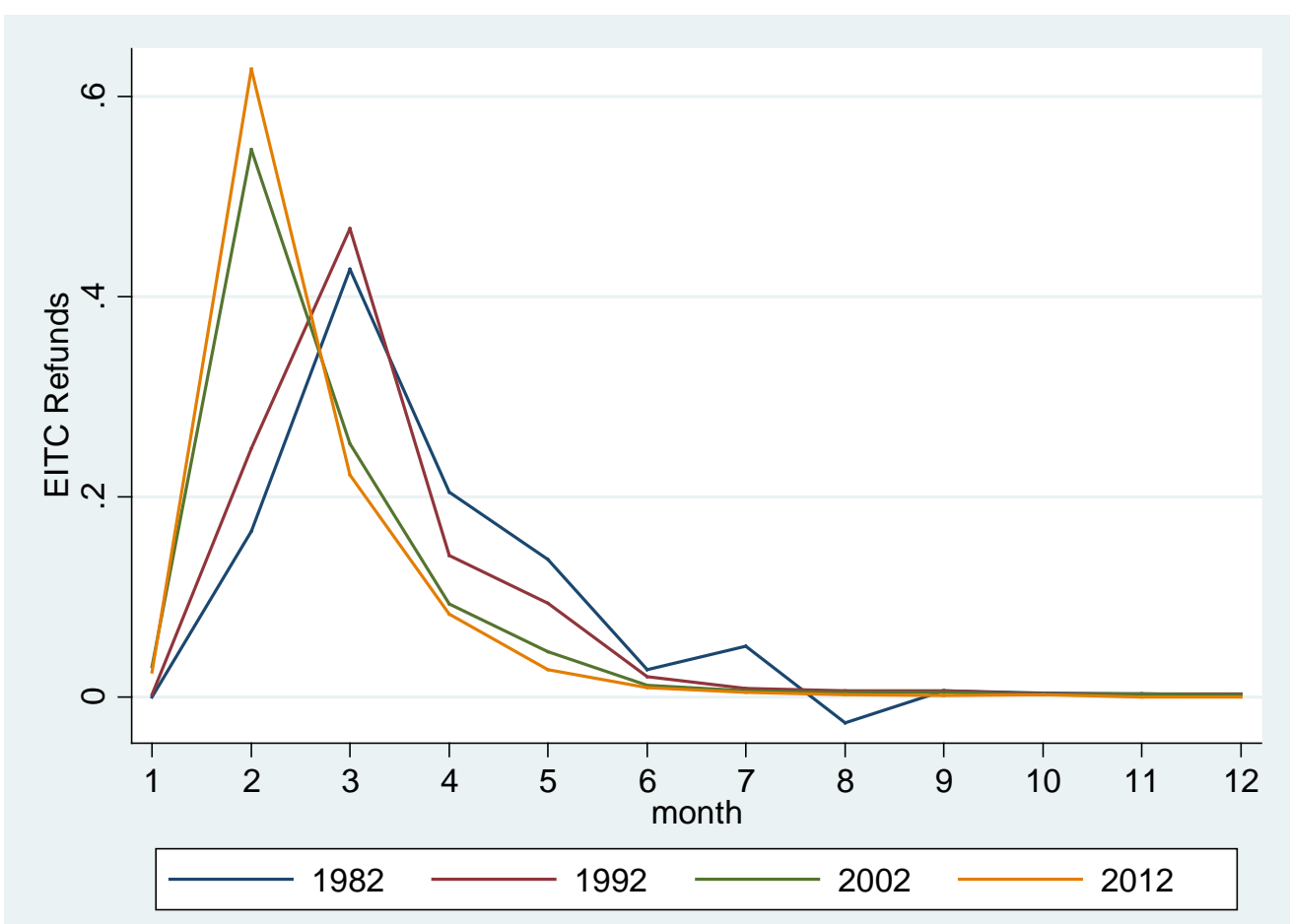

Note: Authors' tabulations from United States Department of the Treasury, Various Issues. 
Figure 5: Average Month of Payment of EITC

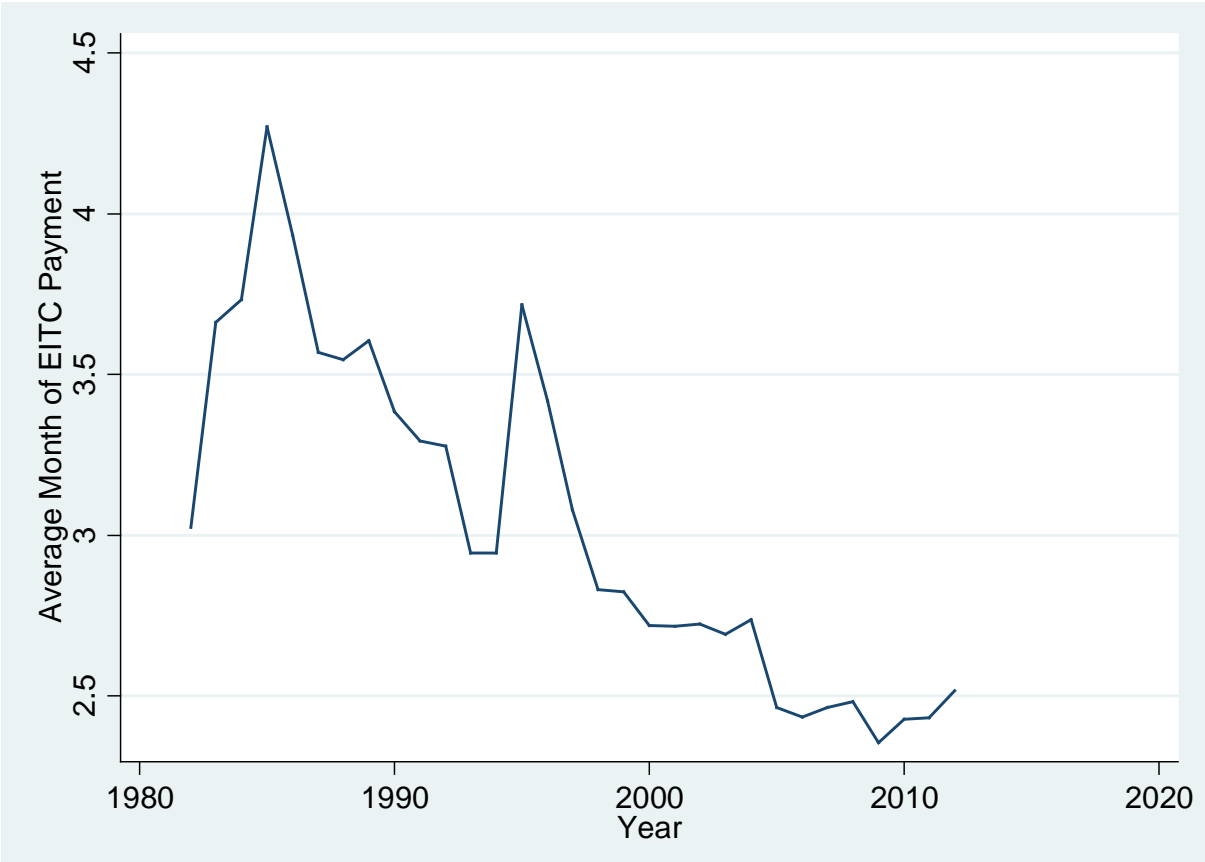

Note: Authors' tabulations from United States Department of the Treasury, Various Issues.

Figure 6: Monthly Payment Shares, Selected Income Support Programs, 2012

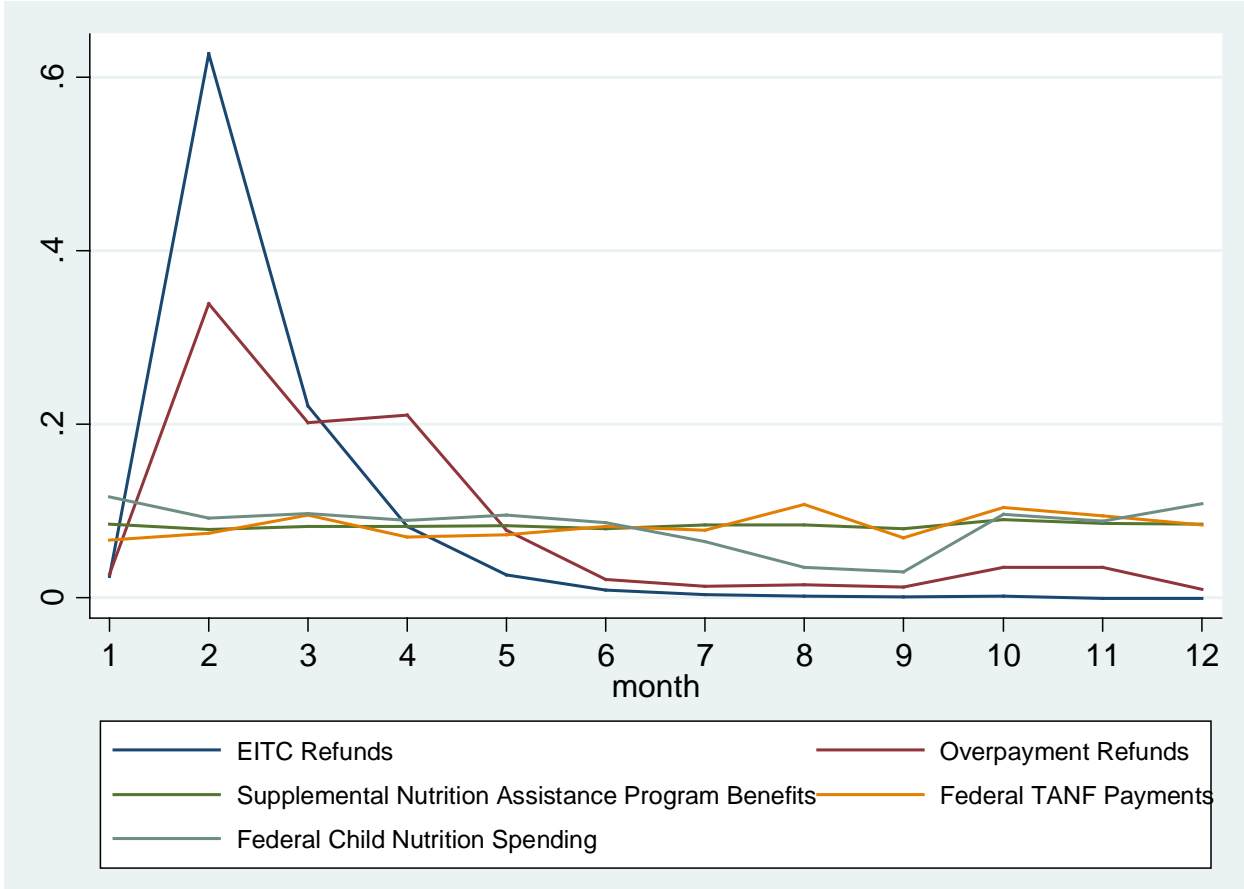

Note: Authors' tabulations from United States Department of the Treasury, Various Issues. 
Table 1: Variable Means

Panel A: Food Expenditure Variables

\begin{tabular}{|c|c|c|c|c|c|c|c|c|}
\hline & \multicolumn{3}{|c|}{ FULL SAMPLE } & \multicolumn{2}{|c|}{ NO EITC } & \multicolumn{3}{|c|}{$\underline{\text { YES EITC }}$} \\
\hline & \multicolumn{2}{|c|}{ Mean } & $\begin{array}{l}\text { Standard } \\
\text { Deviation }\end{array}$ & Mean & $\begin{array}{l}\text { Standard } \\
\text { Deviation }\end{array}$ & \multicolumn{2}{|c|}{ Mean } & $\begin{array}{l}\text { Standard } \\
\text { Deviation }\end{array}$ \\
\hline Food Total & $\$$ & 129.98 & 118.90 & $\$ 132.22$ & 120.52 & $\$$ & 117.38 & 108.38 \\
\hline Food at Home & $\$$ & 79.98 & 81.53 & $\$ 79.65$ & 81.55 & $\$$ & 81.85 & 81.40 \\
\hline Cereal \& Bakery Products & $\$$ & 11.54 & 14.38 & $\$ 11.50$ & 14.47 & $\$$ & 11.74 & 13.86 \\
\hline Meat Poultry Fish and Eggs & $\$$ & 20.68 & 31.51 & $\$ 20.38$ & 31.65 & $\$$ & 22.41 & 30.64 \\
\hline Dairy & $\$$ & 9.32 & 11.11 & $\$ 9.34$ & 11.20 & $\$$ & 9.19 & 10.56 \\
\hline Fresh Fruit and Veg & $\$$ & 8.39 & 12.24 & $\$ 8.40$ & 12.25 & $\$$ & 8.37 & 12.23 \\
\hline Processed Fruit and Veg & $\$$ & 5.03 & 7.67 & $\$ 5.02$ & 7.67 & $\$$ & 5.08 & 7.68 \\
\hline Sweets & $\$$ & 3.06 & 6.77 & 3.08 & 6.88 & $\$$ & 2.92 & 6.08 \\
\hline Non Alcoholic Bevs & $\$$ & 7.32 & 10.49 & $\$ 7.30$ & 10.58 & $\$$ & 7.40 & 9.98 \\
\hline Oils & $\$$ & 2.14 & 4.05 & $\$ \quad 2.11$ & 4.03 & $\$$ & 2.29 & 4.17 \\
\hline Misc Food & $\$$ & 12.52 & 18.11 & $\$ 12.53$ & 18.11 & $\$$ & 12.45 & 18.13 \\
\hline Food Away & $\$$ & 50.00 & 73.19 & $\$ 52.56$ & 75.26 & $\$$ & 35.53 & 58.10 \\
\hline Fast Food* & $\$$ & 24.50 & 33.18 & $\$ 25.14$ & 33.58 & $\$$ & 21.65 & 31.15 \\
\hline Full Service* & $\$$ & 24.51 & 50.91 & $\$ 26.89$ & 53.25 & $\$$ & 13.88 & 36.97 \\
\hline Sugared Beverages & $\$$ & 5.45 & 8.51 & $\$ \quad 5.40$ & 8.55 & $\$$ & 5.72 & 8.26 \\
\hline Healthy Foods & $\$$ & 28.21 & 31.04 & $\$ 28.01$ & 30.90 & $\$$ & 29.31 & 31.83 \\
\hline Junk Foods & $\$$ & 9.85 & 13.93 & $\$ 9.94$ & 14.12 & $\$$ & 9.35 & 12.80 \\
\hline \multicolumn{4}{|c|}{ * Breakdown not available for all years of data } & & & & & \\
\hline ** Average Weekly Spendir & Wit & Heads 1 & $8-65,1982-2 C$ & & & & & \\
\hline
\end{tabular}


Panel B: Socio-Demographic Variables

\begin{tabular}{|c|c|c|c|c|c|c|}
\hline & \multicolumn{2}{|c|}{ FULL SAMPLE } & \multicolumn{2}{|c|}{$\underline{\text { NO EITC }}$} & \multicolumn{2}{|c|}{ YES EITC } \\
\hline & Mean & $\begin{array}{l}\text { Standard } \\
\text { Deviation }\end{array}$ & Mean & $\begin{array}{l}\text { Standard } \\
\text { Deviation }\end{array}$ & Mean & $\begin{array}{l}\text { Standard } \\
\text { Deviation }\end{array}$ \\
\hline Family Size & 2.73 & 1.54 & 2.58 & 1.47 & 3.62 & 1.65 \\
\hline Persons Less Than 18 & 0.84 & 1.17 & 0.71 & 1.10 & 1.58 & 1.28 \\
\hline Persons Over 65 & 0.04 & 0.22 & 0.05 & 0.23 & 0.03 & 0.19 \\
\hline Age of Head & 41.18 & 12.40 & 41.59 & 12.54 & 38.89 & 11.35 \\
\hline Dummy $=1$ if Male Head & 0.57 & 0.49 & 0.60 & 0.49 & 0.41 & 0.49 \\
\hline Dummy=1 if Less Ed Head & 0.41 & 0.49 & 0.38 & 0.49 & 0.59 & 0.49 \\
\hline Weekly Pre-Tax Income (1000s) & 1.25 & 1.11 & 1.36 & 1.15 & 0.62 & 0.55 \\
\hline Dummy=1 if First Interview & 0.50 & 0.50 & 0.50 & 0.50 & 0.50 & 0.50 \\
\hline Dummy=1 if Married & 0.56 & 0.50 & 0.58 & 0.49 & 0.49 & 0.50 \\
\hline Dummy=1 if EITC & 0.15 & 0.36 & 0.00 & 0.00 & 1.00 & 0.00 \\
\hline Imputed EITC AMT & 236.64 & 791.03 & $\$$ & 0.00 & $\$ 1,573.52$ & 1434.29 \\
\hline Imputed State EITC & 13.19 & 106.50 & $\$$ & 0.00 & $\$ \quad 68.62$ & 223.69 \\
\hline Dummy=1 if SNAP Last Year & 0.09 & 0.28 & 0.06 & 0.24 & 0.23 & 0.42 \\
\hline Dummy=1 if SNAP Last Month & 0.06 & 0.24 & 0.04 & 0.20 & 0.18 & 0.38 \\
\hline SNAP Amount Last Year & 135.71 & 705.45 & $\$ 115.42$ & 704.53 & 558.31 & 1576.75 \\
\hline Year & 1998.03 & 8.85 & 1997.61 & 8.95 & 2000.36 & 7.85 \\
\hline Observations & 259555 & & 220521 & & 34335 & \\
\hline
\end{tabular}

Note: Authors' tabulations from BLS, Various Years, deflated using BLS, Consumer Price Index, via Haver Analytics. Federal EITC parameters from Tax Policy Center, 2013. State EITC parameters from National Bureau of Economic Research, 2013. 
Table 2: Category definitions

- Sugar Sweetened Beverages

- Cola drinks, other carbonated drinks, noncarbonated fruit flavored drinks, other noncarbonated (excluding tea and coffee), sports drinks

- Healthy Foods

- Bread other than white, poultry, fish and shellfish, eggs, milk, cheese, other non-ice cream dairy, fruit (excluding juice), vegetables, dried fruit, nuts, prepared salads, baby food.

- Junk Foods

- Cakes and cupcakes, doughnuts, pies tarts and turnovers, hot dogs, ice cream, candy and gum, potato chips and other snacks, prepared desserts. 


\section{Table 3: Baseline Estimates of Food Spending}

\begin{tabular}{|c|c|c|c|c|c|c|c|c|c|c|c|c|c|c|c|c|c|}
\hline & (1) & (2) & (3) & (4) & (5) & (6) & (7) & (8) & (9) & (10) & (11) & (12) & (13) & (14) & (15) & (16) & (17) \\
\hline & Food & $\begin{array}{c}\text { Food at } \\
\text { Home }\end{array}$ & $\begin{array}{l}\text { Cereal } \\
\text { and } \\
\text { Bakery } \\
\text { Products }\end{array}$ & $\begin{array}{l}\text { Meat, } \\
\text { Poultry, } \\
\text { Fish and } \\
\text { Eggs }\end{array}$ & Dairy & $\begin{array}{l}\text { Fresh Fruits } \\
\quad \text { and } \\
\text { Vegetables }\end{array}$ & $\begin{array}{l}\text { Processed } \\
\text { Fruits and } \\
\text { Vegetables }\end{array}$ & Sweets & $\begin{array}{c}\text { Non- } \\
\text { Alcoholic } \\
\text { Drinks }\end{array}$ & Oils & $\begin{array}{l}\text { Other } \\
\text { Food at } \\
\text { Home }\end{array}$ & $\begin{array}{l}\text { Food } \\
\text { Away } \\
\text { From } \\
\text { Home }\end{array}$ & Fast Food & $\begin{array}{c}\text { Full } \\
\text { Service }\end{array}$ & $\begin{array}{c}\text { Sugar } \\
\text { Sweetened } \\
\text { Beverages }\end{array}$ & $\begin{array}{l}\text { Healthy } \\
\text { Foods }\end{array}$ & $\begin{array}{l}\text { Junk } \\
\text { Foods }\end{array}$ \\
\hline \multirow[t]{2}{*}{ Number of Members in $\mathrm{CU}$} & $24.77 * * *$ & $19.11^{* * *}$ & $2.553^{* * *}$ & $6.587^{* * *}$ & $1.938^{* * *}$ & $1.815^{* * *}$ & $1.099 * * *$ & $0.552^{* * *}$ & $1.779 * * *$ & $0.572^{* * *}$ & $2.220^{* * *}$ & $5.659^{* * *}$ & $4.667^{* * *}$ & $0.686^{* * *}$ & $1.329 * * *$ & $6.272^{* * *}$ & $1.670^{* * *}$ \\
\hline & $(0.320)$ & $(0.222)$ & $(0.0401)$ & $(0.0901)$ & $(0.0307)$ & $(0.0349)$ & $(0.0222)$ & (0.0199) & $(0.0305)$ & (0.0119) & (0.0519) & $(0.209)$ & $(0.129)$ & $(0.195)$ & $(0.0253)$ & $(0.0878)$ & $(0.0404)$ \\
\hline \multirow[t]{2}{*}{ \# Children Less than 18} & $-8.580 * * *$ & $-3.316^{* * *}$ & $0.303^{* * *}$ & $-2.689 * * *$ & $0.269 * * *$ & $-0.612^{* * *}$ & $-0.119 * * *$ & $0.167 * * *$ & $-0.815^{* * *}$ & $-0.173^{* * *}$ & $0.353^{* * *}$ & $-5.264 * * *$ & $-2.600 * * *$ & $-2.684 * * *$ & $-0.483^{* * *}$ & $-1.249 * * *$ & $0.583^{* * *}$ \\
\hline & $(0.383)$ & $(0.266)$ & $(0.0479)$ & $(0.108)$ & $(0.0367)$ & $(0.0417)$ & $(0.0265)$ & $(0.0238)$ & $(0.0365)$ & $(0.0142)$ & $(0.0621)$ & $(0.250)$ & $(0.155)$ & $(0.236)$ & $(0.0302)$ & $(0.105)$ & $(0.0483)$ \\
\hline \multirow[t]{2}{*}{ \# Persons Over 64} & $-4.486 * * *$ & -0.710 & 0.0943 & -0.394 & -0.0777 & $0.647^{* * *}$ & $0.129 *$ & -0.00471 & $-0.543^{* * *}$ & $-0.0999 * * *$ & $-0.460 * * *$ & $-3.776 * * *$ & $-1.804 * * *$ & -0.725 & $-0.472^{* * *}$ & $0.998^{* * *}$ & -0.0542 \\
\hline & $(0.988)$ & $(0.684)$ & $(0.124)$ & $(0.278)$ & $(0.0946)$ & $(0.108)$ & $(0.0684)$ & $(0.0613)$ & $(0.0940)$ & $(0.0367)$ & $(0.160)$ & $(0.644)$ & $(0.390)$ & (0.591) & $(0.0785)$ & $(0.272)$ & $(0.125)$ \\
\hline \multirow[t]{2}{*}{ Age of Reference Person } & $1.688^{* * *}$ & $1.246^{* * *}$ & $0.198^{* * *}$ & $0.338^{* * *}$ & $0.150^{* * *}$ & $0.0955^{* * *}$ & $0.0730^{* * *}$ & $0.0605^{* * *}$ & $0.155^{* * *}$ & $0.0346^{* * *}$ & $0.141^{* * *}$ & $0.442^{* * *}$ & $0.153^{* * *}$ & 0.0344 & $0.109 * * *$ & $0.283^{* * *}$ & $0.209^{* * *}$ \\
\hline & $(0.0836)$ & $(0.0579)$ & $(0.0104)$ & $(0.0235)$ & $(0.00800)$ & $(0.00910)$ & $(0.00579)$ & $(0.00519)$ & $(0.00795)$ & $(0.00310)$ & $(0.0135)$ & $(0.0545)$ & $(0.0334)$ & $(0.0506)$ & $(0.00663)$ & $(0.0230)$ & $(0.0106)$ \\
\hline \multirow[t]{2}{*}{ Age of Reference Person Squared } & $-0.0143^{* * *}$ & $0.00719 * *$ & $0.00117^{* *}$ & $0.00158^{* *}$ & $.000979 * *$ & $1.38 \mathrm{e}-06$ & $-0.000408^{* * *}$ & *.000310** & $0.00129^{* *}$ & $-0.000141^{* * *}$ & $* 0.00131 * *$ & $0.00710^{* *}$ & $0.00426^{* *}$ & $7.15 \mathrm{e}-05$ & $-0.00115^{* * *}$ & $0.000625^{*}$ & $0.00150^{* *}$ \\
\hline & $(0.000993)$ & $(0.000688)$ & $(0.000124)$ & $(0.000279)$ & $(9.51 e-05)$ & $(0.000108)$ & $(6.88 \mathrm{e}-05)$ & $(6.16 e-05)$ & $(9.45 e-05)$ & $(3.69 \mathrm{e}-05)$ & $(0.000161)$ & $(0.000648)$ & )$(0.000393)$ & $(0.000596)$ & $(7.87 e-05)$ & $(0.000273)$ & )$(0.000126)$ \\
\hline \multirow[t]{2}{*}{ Dummy $=1$ if Male Head } & $1.112^{* *}$ & $-2.778^{* * *}$ & $-0.390 * * *$ & -0.0677 & $-0.361^{* * *}$ & $-0.681^{* * *}$ & $-0.135^{* * *}$ & $-0.258 * * *$ & $-0.179 * * *$ & $-0.0782^{* * *}$ & $-0.628^{* * *}$ & $3.890^{* * *}$ & $1.638^{* * *}$ & $2.640^{* * *}$ & -0.00615 & $-1.543^{* * *}$ & $-0.619 * * *$ \\
\hline & $(0.460)$ & (0.319) & $(0.0575)$ & $(0.129)$ & $(0.0440)$ & $(0.0501)$ & $(0.0319)$ & $(0.0285)$ & $(0.0438)$ & $(0.0171)$ & $(0.0745)$ & $(0.300)$ & $(0.182)$ & $(0.276)$ & $(0.0366)$ & $(0.127)$ & $(0.0584)$ \\
\hline \multirow[t]{2}{*}{ Dummy $=1$ if Head HS Degree or Less } & $-10.93^{* * *}$ & $-3.166^{* * *}$ & $-0.777^{* * *}$ & $1.621^{* * *}$ & $-0.965 * * *$ & $-1.051^{* * *}$ & $-0.518^{* * *}$ & $-0.305^{* * *}$ & $0.201^{* * *}$ & 0.000465 & $-1.372^{* * *}$ & $-7.762 * * *$ & $-2.522 * * *$ & $-5.882 * * *$ & $0.191^{* * *}$ & $-2.198 * * *$ & $-0.942^{* * *}$ \\
\hline & $(0.455)$ & $(0.315)$ & $(0.0569)$ & $(0.128)$ & $(0.0436)$ & $(0.0495)$ & $(0.0315)$ & $(0.0282)$ & $(0.0433)$ & $(0.0169)$ & $(0.0737)$ & $(0.297)$ & $(0.192)$ & $(0.291)$ & $(0.0361)$ & $(0.125)$ & $(0.0576)$ \\
\hline \multirow[t]{2}{*}{ Real Before Tax Weekly Income } & $25.55 * * *$ & $8.752^{* * *}$ & $1.198^{* * *}$ & $1.821^{* * *}$ & $0.875 * * *$ & $1.345^{* * *}$ & $0.543^{* * *}$ & $0.362^{* * *}$ & $0.720^{* * *}$ & $0.118^{* * *}$ & $1.769 * * *$ & $16.80^{* * *}$ & $3.746^{* * *}$ & $10.28^{* * *}$ & $0.381^{* * *}$ & $3.313^{* * *}$ & $1.217^{* * *}$ \\
\hline & $(0.222)$ & $(0.154)$ & $(0.0278)$ & $(0.0625)$ & $(0.0213)$ & $(0.0242)$ & $(0.0154)$ & $(0.0138)$ & $(0.0211)$ & $(0.00825)$ & $(0.0360)$ & $(0.145)$ & $(0.0815)$ & $(0.124)$ & $(0.0176)$ & $(0.0611)$ & $(0.0281)$ \\
\hline \multirow[t]{2}{*}{ Dummy $=1$ if First Interview } & $8.562^{* * *}$ & $5.372^{* * *}$ & $0.869 * * *$ & $1.410^{* * *}$ & $0.523^{* * *}$ & $0.500^{* * *}$ & $0.382^{* * *}$ & $0.207^{* * *}$ & $0.635^{* * *}$ & $0.152^{* * *}$ & $0.693^{* * *}$ & $3.191^{* * *}$ & $2.281^{* * *}$ & $1.181^{* * *}$ & $0.426^{* * *}$ & $1.880^{* * *}$ & $0.600^{* * *}$ \\
\hline & $(0.417)$ & $(0.289)$ & $(0.0521)$ & $(0.117)$ & $(0.0399)$ & $(0.0454)$ & $(0.0289)$ & $(0.0259)$ & $(0.0397)$ & $(0.0155)$ & $(0.0675)$ & $(0.272)$ & $(0.174)$ & $(0.264)$ & $(0.0331)$ & $(0.115)$ & $(0.0528)$ \\
\hline \multirow[t]{2}{*}{ Dummy $=1$ if Married Head } & $12.68^{* * *}$ & $11.26^{* * *}$ & $1.658^{* * *}$ & $1.979 * * *$ & $1.577 * * *$ & $1.528^{* * *}$ & $0.778^{* * *}$ & $0.549 * * *$ & $0.805^{* * *}$ & $0.340^{* * *}$ & $2.048^{* * *}$ & $1.417^{* * *}$ & $0.585^{* *}$ & $2.265^{* * *}$ & $0.534^{* * *}$ & $4.520^{* * *}$ & $1.822^{* * *}$ \\
\hline & $(0.570)$ & $(0.395)$ & $(0.0712)$ & $(0.160)$ & $(0.0546)$ & $(0.0620)$ & $(0.0395)$ & $(0.0354)$ & $(0.0542)$ & $(0.0212)$ & $(0.0923)$ & $(0.372)$ & $(0.229)$ & $(0.347)$ & $(0.0452)$ & $(0.157)$ & $(0.0722)$ \\
\hline \multirow[t]{2}{*}{ Dummy $=1$ if Black } & $-19.33^{* * *}$ & $-9.762^{* * *}$ & $-1.776^{* * *}$ & $2.837^{* * *}$ & $-3.199 * * *$ & $-1.472^{* * *}$ & -0.0415 & $-0.645^{* * *}$ & $-1.723^{* * *}$ & $-0.170^{* * *}$ & $-3.572^{* * *}$ & $-9.567 * * *$ & $-1.599 * * *$ & $-7.431 * * *$ & $-1.165 * * *$ & $-2.238^{* * *}$ & $-2.532^{* * *}$ \\
\hline & $(0.681)$ & $(0.472)$ & $(0.0851)$ & $(0.192)$ & $(0.0652)$ & $(0.0741)$ & $(0.0472)$ & $(0.0423)$ & $(0.0648)$ & $(0.0253)$ & $(0.110)$ & $(0.444)$ & $(0.279)$ & $(0.423)$ & $(0.0542)$ & $(0.188)$ & $(0.0865)$ \\
\hline \multirow[t]{2}{*}{ Dummy $=1$ if Other Race } & $6.240^{* * *}$ & $1.860^{* * *}$ & $0.292^{* *}$ & $3.886^{* * *}$ & $-2.535 * * *$ & $3.545 * * *$ & $-0.221^{* * *}$ & $-0.339 * * *$ & $-1.149 * * *$ & $-0.224^{* * *}$ & $-1.396 * * *$ & $4.380^{* * *}$ & $1.874^{* * *}$ & $1.786^{* * *}$ & $-1.118^{* * *}$ & $5.394^{* * *}$ & $-1.069 * * *$ \\
\hline & $(0.955)$ & $(0.661)$ & $(0.119)$ & $(0.269)$ & $(0.0914)$ & $(0.104)$ & $(0.0661)$ & $(0.0592)$ & $(0.0908)$ & $(0.0355)$ & $(0.155)$ & $(0.623)$ & $(0.366)$ & $(0.556)$ & $(0.0758)$ & $(0.263)$ & $(0.121)$ \\
\hline \multirow[t]{2}{*}{ Dummy $=1$ if Rural } & $-11.55^{* * *}$ & $-4.553^{* * *}$ & $-0.596 * * *$ & $-1.643^{* * *}$ & $-0.173^{* *}$ & $-1.682^{* * *}$ & $-0.344^{* * *}$ & $0.111^{* *}$ & 0.105 & 0.0395 & $-0.370^{* * *}$ & $-6.995 * * *$ & $-3.387^{* * *}$ & $-3.826 * * *$ & $0.213^{* * *}$ & $-3.715 * * *$ & $-0.311^{* * *}$ \\
\hline & $(0.781)$ & $(0.541)$ & $(0.0976)$ & $(0.220)$ & $(0.0748)$ & $(0.0850)$ & $(0.0541)$ & $(0.0484)$ & $(0.0743)$ & $(0.0290)$ & $(0.126)$ & $(0.509)$ & $(0.344)$ & $(0.521)$ & $(0.0617)$ & $(0.214)$ & $(0.0985)$ \\
\hline \multirow[t]{2}{*}{ Dummy $=1$ if EITC Imputed } & $-6.001 * * *$ & $-3.405^{* * *}$ & $-1.024 * * *$ & -0.161 & $-0.665^{* * *}$ & $0.263^{* * *}$ & $-0.201^{* * *}$ & $-0.344^{* * *}$ & $-0.175^{* * *}$ & $-0.0769 * * *$ & $-1.020^{* * *}$ & $-2.596 * * *$ & $-2.361^{* * *}$ & 0.346 & $-0.167^{* * *}$ & -0.00182 & $-1.247^{* * *}$ \\
\hline & $(0.650)$ & $(0.450)$ & $(0.0813)$ & $(0.183)$ & $(0.0623)$ & $(0.0708)$ & $(0.0450)$ & $(0.0403)$ & $(0.0619)$ & $(0.0242)$ & $(0.105)$ & $(0.424)$ & $(0.251)$ & $(0.381)$ & $(0.0515)$ & $(0.179)$ & $(0.0823)$ \\
\hline \multirow[t]{2}{*}{ Constant } & $4.880^{* *}$ & $-12.36^{* * *}$ & $-2.867^{* * *}$ & $-3.988 * * *$ & $1.399 * * *$ & $-1.443^{* * *}$ & -0.244 & $-0.937^{* * *}$ & $-1.580^{* * *}$ & $-0.575^{* * *}$ & $-2.130 * * *$ & $17.24^{* * *}$ & $12.59 * * *$ & $5.162^{* * *}$ & $-0.888^{* * *}$ & $-1.658^{* * *}$ & $-3.292^{* * *}$ \\
\hline & (2.203) & $(1.526)$ & $(0.275)$ & $(0.620)$ & $(0.211)$ & $(0.240)$ & $(0.153)$ & $(0.137)$ & $(0.210)$ & $(0.0818)$ & $(0.357)$ & $(1.437)$ & $(0.856)$ & $(1.297)$ & $(0.175)$ & $(0.606)$ & $(0.279)$ \\
\hline Observa & 259,555 & 259,555 & 259,555 & 259,555 & 259,555 & 555 & 259,555 & 259,555 & 259,555 & 259,555 & 259,555 & 259,555 & 135,164 & 135,164 & 248,712 & 248,712 & 248,712 \\
\hline R-squar & 0.203 & 0.187 & 0.148 & 0.102 & 0.162 & 0.109 & 0.082 & 0.052 & 0.073 & 0.053 & 0.098 & 0.105 & 0.072 & 0.094 & 0.062 & 0.152 & 0.107 \\
\hline \multicolumn{18}{|l|}{ Standard errors in parentheses } \\
\hline$* * * p<0.01, * * p<0.05, * p<0.1$ & & & & & & & & & & & & & & & & & \\
\hline
\end{tabular}

Note: Authors' tabulations from BLS, Various Years, deflated using BLS, Consumer Price Index, via Haver Analytics. 
Table 4: Seasonality Among EITC Recipients

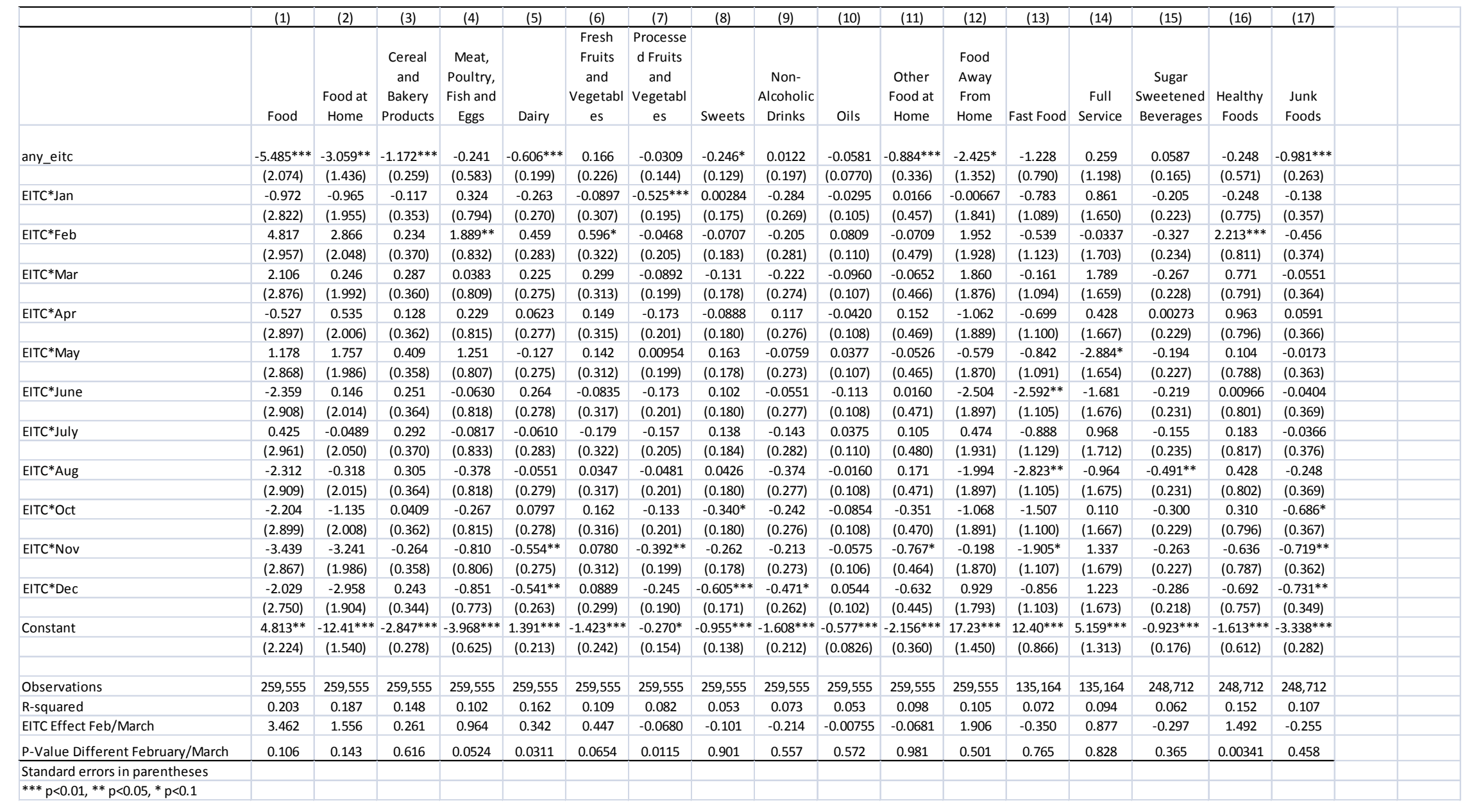

Note: Authors' tabulations from BLS, Various Years, deflated using BLS, Consumer Price Index, via Haver Analytics. 
Table 5: Increase in Spending, Share of EITC Paid Out in the Month

\begin{tabular}{|c|c|c|c|c|c|c|c|c|c|c|c|c|c|c|c|c|c|}
\hline & (1) & (2) & (3) & (4) & (5) & (6) & (7) & (8) & (9) & (10) & (11) & (12) & (13) & (14) & (15) & (16) & (17) \\
\hline VARIABLES & Food & $\begin{array}{c}\text { Food at } \\
\text { Home }\end{array}$ & $\begin{array}{c}\begin{array}{c}\text { Cereal } \\
\text { and } \\
\text { Bakery } \\
\text { Products }\end{array} \\
\end{array}$ & $\begin{array}{l}\text { Meat, } \\
\text { Poultry, } \\
\text { Fish and } \\
\text { Eggs } \\
\end{array}$ & Dairy & $\begin{array}{c}\text { Fresh Fruits } \\
\text { and } \\
\text { Vegetables }\end{array}$ & $\begin{array}{c}\text { Processed } \\
\text { Fruits and } \\
\text { Vegetables }\end{array}$ & Sweets & $\begin{array}{c}\text { Non- } \\
\text { Alcoholic } \\
\text { Drinks } \\
\end{array}$ & Oils & $\begin{array}{c}\text { Other } \\
\text { Food at } \\
\text { Home }\end{array}$ & $\begin{array}{l}\text { Food } \\
\text { Away } \\
\text { From } \\
\text { Home } \\
\end{array}$ & Fast Food & $\begin{array}{c}\text { Full } \\
\text { Service } \\
\end{array}$ & $\begin{array}{c}\text { Sugar } \\
\text { Sweetene } \\
d \\
\text { Beverages }\end{array}$ & $\begin{array}{c}\text { Healthy } \\
\text { Foods }\end{array}$ & $\begin{array}{c}\text { Junk } \\
\text { Foods } \\
\end{array}$ \\
\hline \multirow[t]{2}{*}{ Dummy $=1$ if EITC Eligible } & $-6.899 * * *$ & $-3.945 * * *$ & $-1.041^{* * *}$ & $-0.386^{*}$ & $-0.768 * * *$ & $0.174^{* *}$ & $-0.225 * * *$ & $-0.362^{* * *}$ & $-0.183^{* * *}$ & $-0.0788^{* * *}$ & $*-1.076^{* * *}$ & $-2.954 * * *$ & $-2.548^{* * *}$ & 0.341 & $-0.162^{* * *}$ & $-0.352^{*}$ & $-1.244^{* * *}$ \\
\hline & $(0.724)$ & $(0.501)$ & $(0.0905)$ & $(0.204)$ & $(0.0693)$ & $(0.0788)$ & $(0.0501)$ & $(0.0449)$ & $(0.0688)$ & $(0.0269)$ & $(0.117)$ & $(0.472)$ & $(0.278)$ & $(0.422)$ & $(0.0573)$ & $(0.199)$ & $(0.0916)$ \\
\hline \multirow[t]{2}{*}{ EITC*Share in Month } & $12.64^{* * *}$ & $7.931^{* * *}$ & 0.526 & $3.440^{* * *}$ & $1.366^{* * *}$ & $1.032^{* *}$ & 0.317 & 0.314 & 0.225 & 0.0331 & 0.678 & $4.705^{*}$ & $2.574^{*}$ & 0.413 & 0.0416 & $4.532^{* * *}$ & 0.383 \\
\hline & $(4.002)$ & $(2.771)$ & $(0.500)$ & $(1.126)$ & $(0.383)$ & $(0.436)$ & $(0.277)$ & $(0.248)$ & $(0.381)$ & (0.149) & $(0.648)$ & $(2.610)$ & $(1.476)$ & $(2.238)$ & $(0.316)$ & $(1.097)$ & $(0.505)$ \\
\hline \multirow[t]{2}{*}{ Constant } & $5.040^{* *}$ & $-12.26^{* * *}$ & $-2.860^{* * *}$ & $-3.944^{* * *}$ & $1.417^{* * *}$ & $-1.430^{* * *}$ & -0.240 & $-0.933 * * *$ & $-1.577^{* * *}$ & $-0.574^{* * *}$ & $-2.121^{* * *}$ & $17.30^{* * *}$ & $12.63^{* * *}$ & $5.167^{* * *}$ & $-0.888^{* * *}$ & $-1.600^{* * *}$ & $-3.287^{* * *}$ \\
\hline & $(2.204)$ & $(1.526)$ & $(0.276)$ & $(0.620)$ & $(0.211)$ & $(0.240)$ & $(0.153)$ & $(0.137)$ & $(0.210)$ & $(0.0819)$ & $(0.357)$ & (1.437) & $(0.856)$ & (1.298) & $(0.175)$ & $(0.606)$ & $(0.279)$ \\
\hline Observations & 259,555 & 259,555 & 259,555 & 259,555 & 259,555 & 259,555 & 259,555 & 259,555 & 259,555 & 259,555 & 259,555 & 259,555 & 135,164 & 135,164 & 248,712 & 248,712 & 248,712 \\
\hline R-squared & 0.203 & 0.187 & 0.148 & 0.102 & 0.162 & 0.109 & 0.082 & 0.052 & 0.073 & 0.053 & 0.098 & 0.105 & 0.072 & 0.094 & 0.062 & 0.152 & 0.107 \\
\hline Percent Increase & 0.0972 & 0.0992 & 0.0456 & 0.166 & 0.147 & 0.123 & 0.0631 & 0.103 & 0.0307 & 0.0155 & 0.0542 & 0.0941 & 0.105 & 0.0169 & 0.00763 & 0.161 & 0.0389 \\
\hline Percent of Average Benefit & 0.0345 & 0.0216 & 0.00143 & 0.00939 & 0.00373 & 0.00282 & 0.000866 & 0.000856 & 0.000613 & 9.04e-05 & 0.00185 & 0.0128 & 0.00703 & 0.00113 & 0.000113 & 0.0124 & 0.00105 \\
\hline \multicolumn{2}{|c|}{ Standard errors in parentheses } & & & & & & & & & & & & & & & & \\
\hline${ }^{* * *} p<0.01,{ }^{* *} p<0.05, * p<0.1$ & & & & & & & & & & & & & & & & & \\
\hline
\end{tabular}

Note: Authors' tabulations from BLS, Various Years, deflated using BLS, Consumer Price Index, via Haver Analytics. 
Table 6: Effect of EITC Share on Spending Increases Across Different Population Subgroups

\begin{tabular}{|c|c|c|c|c|c|c|c|c|c|c|c|c|}
\hline & (1) & (2) & (3) & (4) & (5) & (6) & (7) & (8) & (9) & (10) & (11) & (12) \\
\hline & Baseline & $\begin{array}{c}\text { Households } \\
\text { With Kids }\end{array}$ & $\begin{array}{c}\text { Head LE } \\
\text { High School }\end{array}$ & $\begin{array}{c}\text { Income } \\
<=60 \mathrm{k}\end{array}$ & $\begin{array}{l}\text { Without No } \\
\text { Kid EITC }\end{array}$ & $\begin{array}{c}\text { Dropping } \\
\text { EITC } \\
\text { Amt }<\$ 50\end{array}$ & $\begin{array}{c}\text { Dropping } \\
\quad \text { EITC } \\
\text { Amt }<\$ 300\end{array}$ & $\begin{array}{c}\text { Dropping } \\
\text { EITC } \\
\text { Amt }<\$ 1000\end{array}$ & $\begin{array}{c}\text { First } \\
\text { Interview }\end{array}$ & $\begin{array}{l}\text { Second } \\
\text { Interview }\end{array}$ & Male Head & $\begin{array}{c}\text { Female } \\
\text { Head }\end{array}$ \\
\hline & \multicolumn{12}{|c|}{ Total Food Spending } \\
\hline \multirow[t]{2}{*}{ EITCShare in Month } & $12.64^{* * *}$ & 6.844 & 7.681 & $10.96 * * *$ & $12.37^{* * *}$ & $13.20^{* * *}$ & $13.77^{* * *}$ & $11.84^{* *}$ & $21.42^{* * *}$ & 4.015 & $14.97^{* *}$ & $10.34^{*}$ \\
\hline & $(4.002)$ & (5.259) & (4.953) & (3.577) & $(4.435)$ & $(4.072)$ & $(4.436)$ & $(5.287)$ & $(5.765)$ & $(5.554)$ & (6.118) & (5.345) \\
\hline Percent Increase & 0.0972 & 0.0435 & 0.0650 & 0.113 & 0.0945 & 0.101 & 0.105 & 0.0903 & 0.159 & 0.0319 & 0.107 & 0.0881 \\
\hline \multirow[t]{2}{*}{ Percent of Average Benefit } & 0.0345 & 0.0157 & 0.0198 & 0.0293 & 0.0280 & 0.0345 & 0.0304 & 0.0195 & 0.0585 & 0.0130 & 0.0472 & 0.0258 \\
\hline & \multicolumn{12}{|c|}{ Food at Home } \\
\hline \multirow[t]{2}{*}{ EITC $\star$ Share in Month } & $7.931^{* * *}$ & 5.660 & 5.535 & $6.719 * *$ & $8.910^{* * *}$ & $8.160^{* * *}$ & $7.492^{* *}$ & $7.322^{* *}$ & $13.09 * * *$ & 2.838 & $10.53^{* *}$ & 5.040 \\
\hline & $(2.771)$ & (3.856) & $(3.717)$ & $(2.647)$ & $(3.077)$ & $(2.819)$ & $(3.068)$ & (3.646) & $(4.026)$ & (3.814) & $(4.323)$ & (3.598) \\
\hline Percent Increase & 0.0992 & 0.0548 & 0.0702 & 0.105 & 0.111 & 0.102 & 0.0934 & 0.0914 & 0.158 & 0.0367 & 0.125 & 0.0679 \\
\hline \multirow{2}{*}{ Percent of Average Benefit } & 0.0216 & 0.0130 & 0.0143 & 0.0180 & 0.0202 & 0.0213 & 0.0165 & 0.0121 & 0.0358 & 0.00919 & 0.0332 & 0.0126 \\
\hline & \multicolumn{12}{|c|}{ Fresh Fruit and Vegetables } \\
\hline \multirow[t]{2}{*}{ EITC ${ }^{\star}$ Share in Month } & $1.032^{* *}$ & $1.035^{*}$ & 0.825 & $0.994^{* *}$ & $1.318^{* * *}$ & $1.188 * * *$ & $1.120^{* *}$ & $1.756^{* * *}$ & $1.590^{* *}$ & 0.481 & 0.885 & $1.093^{*}$ \\
\hline & $(0.436)$ & $(0.588)$ & $(0.544)$ & $(0.403)$ & $(0.483)$ & $(0.443)$ & $(0.483)$ & $(0.575)$ & $(0.632)$ & $(0.601)$ & $(0.675)$ & $(0.571)$ \\
\hline Percent Increase & 0.123 & 0.101 & 0.109 & 0.154 & 0.157 & 0.141 & 0.133 & 0.208 & 0.184 & 0.0591 & 0.102 & 0.136 \\
\hline \multirow[t]{2}{*}{ Percent of Average Benefit } & 0.00282 & 0.00237 & 0.00213 & 0.00266 & 0.00299 & 0.00311 & 0.00247 & 0.00289 & 0.00434 & 0.00156 & 0.00279 & 0.00272 \\
\hline & \multicolumn{12}{|c|}{ Food Away from Home } \\
\hline \multirow[t]{2}{*}{ EITC^Share in Month } & $4.705^{*}$ & 1.184 & 2.146 & $4.242^{* *}$ & 3.461 & $5.036^{*}$ & $6.278^{* *}$ & 4.519 & $8.328^{* *}$ & 1.177 & 4.435 & 5.303 \\
\hline & (2.610) & (3.125) & $(2.858)$ & (2.123) & $(2.890)$ & $(2.659)$ & $(2.901)$ & (3.470) & (3.719) & $(3.664)$ & (3.947) & (3.533) \\
\hline Percent Increase & 0.0941 & 0.0218 & 0.0546 & 0.127 & 0.0687 & 0.101 & 0.124 & 0.0886 & 0.161 & 0.0243 & 0.0806 & 0.123 \\
\hline \multirow[t]{2}{*}{ Percent of Average Benefit } & 0.0128 & 0.00271 & 0.00554 & 0.0114 & 0.00784 & 0.0132 & 0.0138 & 0.00744 & 0.0227 & 0.00381 & 0.0140 & 0.0132 \\
\hline & \multicolumn{12}{|c|}{ Healthy Food } \\
\hline \multirow[t]{2}{*}{ EITC ${ }^{\star}$ Share in Month } & $4.532^{* * *}$ & $4.421 * * *$ & $2.347^{*}$ & $3.787^{* * *}$ & $5.104^{* * *}$ & $4.875^{* * *}$ & $4.196^{* * *}$ & $4.422^{* * *}$ & $5.982^{* * *}$ & $3.063^{* *}$ & $4.877^{* * *}$ & $4.073^{* * *}$ \\
\hline & $(1.097)$ & $(1.510)$ & $(1.423)$ & $(1.051)$ & $(1.215)$ & $(1.116)$ & $(1.213)$ & $(1.441)$ & $(1.586)$ & $(1.517)$ & $(1.693)$ & (1.443) \\
\hline Percent Increase & 0.161 & 0.125 & 0.0874 & 0.167 & 0.180 & 0.173 & 0.148 & 0.157 & 0.205 & 0.112 & 0.167 & 0.152 \\
\hline \multirow[t]{2}{*}{ Percent of Average Benefit } & 0.0124 & 0.0101 & 0.00606 & 0.0101 & 0.0116 & 0.0128 & 0.00925 & 0.00728 & 0.0163 & 0.00992 & 0.0154 & 0.0101 \\
\hline & \multicolumn{12}{|c|}{ Junk Food } \\
\hline \multirow[t]{2}{*}{ EITC ${ }^{\star}$ Share in Month } & 0.383 & -0.645 & 0.287 & 0.424 & 0.497 & 0.249 & -0.00501 & -0.436 & 0.466 & 0.297 & 0.704 & 0.0860 \\
\hline & $(0.505)$ & $(0.688)$ & $(0.631)$ & $(0.449)$ & $(0.561)$ & $(0.514)$ & $(0.561)$ & $(0.669)$ & $(0.746)$ & $(0.683)$ & $(0.785)$ & $(0.657)$ \\
\hline Percent Increase & 0.0389 & -0.0500 & 0.0313 & 0.0565 & 0.0500 & 0.0253 & -0.000506 & -0.0440 & 0.0459 & 0.0311 & 0.0683 & 0.00931 \\
\hline Percent of Average Benefit & 0.00105 & -0.00148 & 0.000743 & 0.00113 & 0.00112 & 0.000652 & $-1.10 \mathrm{e}-05$ & -0.000718 & 0.00127 & 0.000961 & 0.00222 & 0.000214 \\
\hline Observations & 248,712 & 110,885 & 102,623 & 140,269 & 241,498 & 247,139 & 240,987 & 231,267 & 123,310 & 125,402 & 143,404 & 105,308 \\
\hline Standard errors in parenth & & & & & & & & & & & & \\
\hline${ }^{* * *} p<0.01, * * p<0.05, * p<0.1$ & & & & & & & & & & & & \\
\hline
\end{tabular}

Note: Authors' tabulations from BLS, Various Years, deflated using BLS, Consumer Price Index, via Haver Analytics. 
Table 7: Effect of EITC Share on Spending Increases Across Different Years

\begin{tabular}{|c|c|c|c|c|}
\hline & (1) & (2) & (3) & (4) \\
\hline & Baseline & $1982-1987$ & 1988-1995 & $1996+$ \\
\hline & \multicolumn{4}{|c|}{ Total Food Spending } \\
\hline \multirow[t]{2}{*}{ EITC*Share in Month } & $12.64^{* * *}$ & -0.497 & $21.87^{* *}$ & $11.62^{* *}$ \\
\hline & $(4.002)$ & (13.46) & (9.582) & $(4.882)$ \\
\hline Percent Increase & 0.0972 & -0.00374 & 0.164 & 0.0909 \\
\hline \multirow[t]{2}{*}{ Percent of Average Benefit } & 0.0345 & -0.00357 & 0.0863 & 0.0277 \\
\hline & \multicolumn{4}{|c|}{ Food at Home } \\
\hline \multirow[t]{2}{*}{ EITC*Share in Month } & $7.931^{* * *}$ & 1.350 & $20.69 * * *$ & $6.398^{* *}$ \\
\hline & $(2.771)$ & $(10.13)$ & $(7.171)$ & (3.238) \\
\hline Percent Increase & 0.0992 & 0.0161 & 0.244 & 0.0828 \\
\hline \multirow[t]{2}{*}{ Percent of Average Benefit } & 0.0216 & 0.00968 & 0.0817 & 0.0152 \\
\hline & \multicolumn{4}{|c|}{ Fresh Fruit and Vegetables } \\
\hline \multirow[t]{2}{*}{ EITC*Share in Month } & $1.032^{* *}$ & -1.713 & 1.524 & $1.083^{* *}$ \\
\hline & $(0.436)$ & $(1.456)$ & (1.098) & $(0.525)$ \\
\hline Percent Increase & 0.123 & -0.218 & 0.185 & 0.126 \\
\hline \multirow[t]{2}{*}{ Percent of Average Benefit } & 0.00282 & -0.0123 & 0.00602 & 0.00258 \\
\hline & & \multicolumn{3}{|c|}{ Food Away from Home } \\
\hline \multirow[t]{2}{*}{ EITC*Share in Month } & 4.705* & -1.848 & 1.183 & 5.224 \\
\hline & (2.610) & (8.232) & $(5.885)$ & (3.272) \\
\hline Percent Increase & 0.0941 & -0.0375 & 0.0242 & 0.103 \\
\hline \multirow[t]{2}{*}{ Percent of Average Benefit } & 0.0128 & -0.0132 & 0.00467 & 0.0124 \\
\hline & & \multicolumn{2}{|c|}{ Healthy Food } & \\
\hline \multirow[t]{2}{*}{ EITC*Share in Month } & $4.532 * * *$ & 2.805 & $8.825 * * *$ & $3.800 * * *$ \\
\hline & $(1.097)$ & (3.893) & $(2.720)$ & $(1.310)$ \\
\hline Percent Increase & 0.161 & 0.0996 & 0.323 & 0.133 \\
\hline \multirow[t]{2}{*}{ Percent of Average Benefit } & 0.0124 & 0.0201 & 0.0348 & 0.00905 \\
\hline & \multicolumn{4}{|c|}{ Junk Food } \\
\hline \multirow[t]{2}{*}{ EITC*Share in Month } & 0.383 & 0.0807 & $3.077^{* *}$ & 0.0267 \\
\hline & $(0.505)$ & (1.658) & $(1.325)$ & $(0.603)$ \\
\hline Percent Increase & 0.0389 & 0.00880 & 0.295 & 0.00271 \\
\hline Percent of Average Benefit & 0.00105 & 0.000579 & 0.0121 & $6.35 \mathrm{e}-05$ \\
\hline Observations & 259,555 & 45,269 & 51,188 & 163,098 \\
\hline \multicolumn{2}{|c|}{ Standard errors in parentheses } & & & \\
\hline \multicolumn{2}{|l|}{$* * * p<0.01, * * p<0.05, * p<0.1$} & & & \\
\hline
\end{tabular}

Note: Authors' tabulations from BLS, Various Years, deflated using BLS, Consumer Price Index, via Haver Analytics. 
Table 8: Effect of EITC Share on Spending Increases Across Different Population Subgroups, First Interview Only

\begin{tabular}{|c|c|c|c|c|}
\hline & $(1)$ & $(2)$ & $(3)$ & (4) \\
\hline & Baseline & 1982-1987 & 1988-1994 & $1995+$ \\
\hline & \multicolumn{4}{|c|}{ Total Food Spending } \\
\hline \multirow[t]{2}{*}{ EITC*Share in Month } & $21.42^{* * *}$ & 15.21 & $28.97 * *$ & $19.10^{* * *}$ \\
\hline & $(5.765)$ & $(18.74)$ & $(13.58)$ & (7.101) \\
\hline Percent Increase & 0.159 & 0.111 & 0.211 & 0.144 \\
\hline \multirow[t]{2}{*}{ Percent of Average Benefit } & 0.0585 & 0.109 & 0.114 & 0.0455 \\
\hline & \multicolumn{4}{|c|}{ Food at Home } \\
\hline \multirow[t]{2}{*}{ EITC*Share in Month } & $13.09 * * *$ & 15.38 & $29.51^{* * *}$ & $9.377^{* *}$ \\
\hline & $(4.026)$ & $(14.28)$ & $(10.44)$ & $(4.721)$ \\
\hline Percent Increase & 0.158 & 0.179 & 0.338 & 0.117 \\
\hline \multirow[t]{2}{*}{ Percent of Average Benefit } & 0.0358 & 0.110 & 0.116 & 0.0223 \\
\hline & \multicolumn{4}{|c|}{ Fresh Fruit and Vegetables } \\
\hline \multirow[t]{2}{*}{ EITC*Share in Month } & $1.590 * *$ & -1.159 & $3.562^{* *}$ & $1.324^{*}$ \\
\hline & $(0.632)$ & $(2.030)$ & $(1.640)$ & $(0.759)$ \\
\hline Percent Increase & 0.184 & -0.143 & 0.418 & 0.150 \\
\hline \multirow[t]{2}{*}{ Percent of Average Benefit } & 0.00434 & -0.00831 & 0.0141 & 0.00315 \\
\hline & & \multicolumn{3}{|c|}{ Food Away from Home } \\
\hline \multirow[t]{2}{*}{ EITC*Share in Month } & $8.328^{* *}$ & -0.170 & -0.538 & $9.722 * *$ \\
\hline & (3.719) & $(11.26)$ & (7.982) & (4.739) \\
\hline Percent Increase & 0.161 & -0.00336 & -0.0108 & 0.185 \\
\hline \multirow[t]{2}{*}{ Percent of Average Benefit } & 0.0227 & -0.00122 & -0.00212 & 0.0231 \\
\hline & & \multicolumn{2}{|c|}{ Healthy Food } & \\
\hline \multirow[t]{2}{*}{ EITC*Share in Month } & $5.982 * * *$ & 5.465 & $12.85^{* * *}$ & $4.524^{* *}$ \\
\hline & $(1.586)$ & $(5.531)$ & $(3.926)$ & $(1.899)$ \\
\hline Percent Increase & 0.205 & 0.188 & 0.458 & 0.153 \\
\hline \multirow[t]{2}{*}{ Percent of Average Benefit } & 0.0163 & 0.0392 & 0.0507 & 0.0108 \\
\hline & \multicolumn{4}{|c|}{ Junk Food } \\
\hline \multirow[t]{2}{*}{ EITC*Share in Month } & 0.466 & 1.164 & 2.262 & 0.174 \\
\hline & $(0.746)$ & $(2.344)$ & $(1.988)$ & $(0.891)$ \\
\hline Percent Increase & 0.0459 & 0.124 & 0.209 & 0.0171 \\
\hline Percent of Average Benefit & 0.00127 & 0.00835 & 0.00892 & 0.000414 \\
\hline Observations & 128,606 & 22,500 & 25,530 & 80,576 \\
\hline \multicolumn{5}{|l|}{ Standard errors in parentheses } \\
\hline$* * * p<0.01, * * p<0.05, * p<0.1$ & & & & \\
\hline
\end{tabular}

Note: Authors' tabulations from BLS, Various Years, deflated using BLS, Consumer Price Index, via Haver Analytics. 
Appendix A: Quality of EITC imputation

As mentioned in the body of the paper, we impute EITC receipt based on earnings, family structure and the prior year's EITC schedule. In this Appendix, we compare variables from the results of our imputation procedure to data on EITC expenditures and receipt as published by the IRS in the Statistics of Income (SOI) Publication. Each year the IRS releases data on the number of recipient families, the amount of money spent on the program and the average credit per recipient family. We compare aggregate and average data from SOI to average and aggregate data imputed from the CEX. We perform our analysis both for all families and for just those families where we have high quality income data. Prior to 2004, we only have high quality data for "complete income reporters" which means that the household provided data on at least one major income source. Beginning in 2004, we are able to include all households due to the advent of income imputation.

For these comparisons, we compare survey data from one year to SOI data from the prior tax year. We do this because EITC payments related to one tax year are received in the following year and our imputation procedure is based on the prior year's tax schedule.

In Figure A1, we compare total spending on the EITC program in the CEX with total spending from the SOI. The CEX data are quite a bit below the SOI data. Prior to 2004, much of this is due to the fact that that sample of complete income reporters are the only ones for whom we can reasonable impute EITC and the survey weights are such that complete reporters do not represent the entire population. However after 2004, we still are only capturing about two-thirds of EITC spending.

In Figures A2 and A3, we break down spending on the EITC program into the average benefit per recipient (A2) and the number of beneficiaries (A3). As shown in Figure $A 2$, the average imputed credit tracks the SOI data fairly closely, but always lies below it. Because a CU can contain more than one tax unit, we would expect there to be higher benefits per CU on average. The fact that the average CU has a lower benefit could arise from three different sources. First, we are assuming that take up is $100 \%$. If households with benefits below a certain amount did not take them up, we would see lower average benefits in the survey data than in the actual data. However, this phenomenon would also lead us to expect to see a greater number of recipient households in the imputed data than in the SOI data which we do not see (Figure A3) and higher total spending in the imputed data which we also do not see (Figure A1). Second, if households underreported eligible children, we would expect to see lower imputed benefits per recipient household. This would only be relevant once there were different credits 
based on the number of children (1991-) or a credit for childless households (1994-). Prior to those dates underreporting of children would influence eligibility, but not benefits given eligibility. Third, we could see lower average benefits if there was misreporting of income. If income was underreported in the phase in range, we would see lower imputed benefits. If income was over-reported in the phase out range we would also see lower benefits.

When we display the imputed number of beneficiaries (A3), we see that this is also lower than the number of beneficiary tax returns reported in the SOI. We would expect this prior to 2004, when we cannot impute receipt for all people in the survey, but this pattern persists after 2004 as well. There are also a number of forces that could be at work here. First, a CU can contain many tax units and more than one tax unit may receive the EITC. In Figure A6, we display the number of tax units receiving the EITC in our data. As mentioned in the body of the paper, we break CUs into tax units in order to properly impute the EITC. This bias works in the correct direction, but is small. Second, households could be misreporting the number of children. In particular, households with children may be reporting that they don't have children so our imputation procedure mistakenly labels them as ineligible. Households may also report that they have fewer children than they have. Households with more children receive EITC payments for a wider range of incomes. We do not think that the underreporting of children in a major issue because the total number of children in the CEX is similar to the total number in the US according to Census data. However, we may be incorrectly assigning some children to tax units within the household. In particular, we could be assigning children to tax units with no earned income or too high earned income while they belong in tax units with income within the EITC range. However, this bias is likely to be small because most CUs only contain one tax unit. Third, tax units with income may report that they have no income and therefore appear ineligible. Underreporting of income among households with some income would make households more likely to be eligible for the EITC not less likely. To investigate the role of income underreporting further, we compare pretax income reported in the CEX to Census income data. In Figure A5, we display household median pre-tax income by year according to the CEX and the Census. We chose to look at median income rather than mean income because the CEX income data is top coded making mean comparisons inappropriate. This graph shows some underreporting of income in the CEX.

Income underreporting can explain the patterns in Figures A2 and A3 if some CEX tax units report having no income that have some income, and among households with income some in the phase in range report having less income in the survey than they report to the IRS. Households 
reporting having no income would lower our measure of the number of eligible households while households reporting that they have less income in the phase in range would lower our estimate of benefits given eligibility. This seems to be the explanation most consistent with the pattern in the data. 
Figure A1: Total EITC Spending, IRS Statistics of Income vs. CEX Imputation

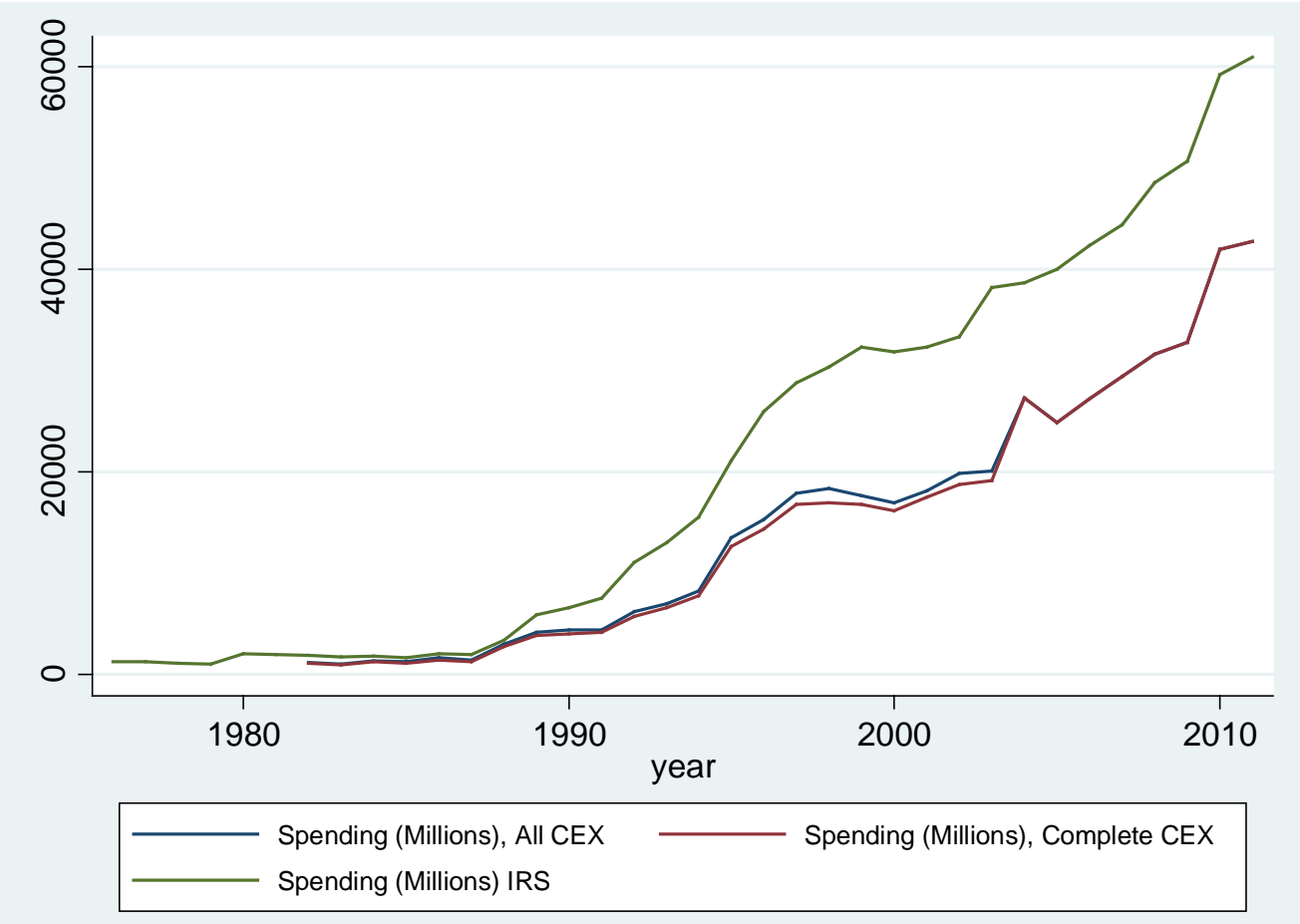

Note: Authors' tabulations based on BLS, Various Years and IRS, Various Years.

Figure A2: Average Benefit, IRS Recipient Families vs. Eligible CEX Consumer Units

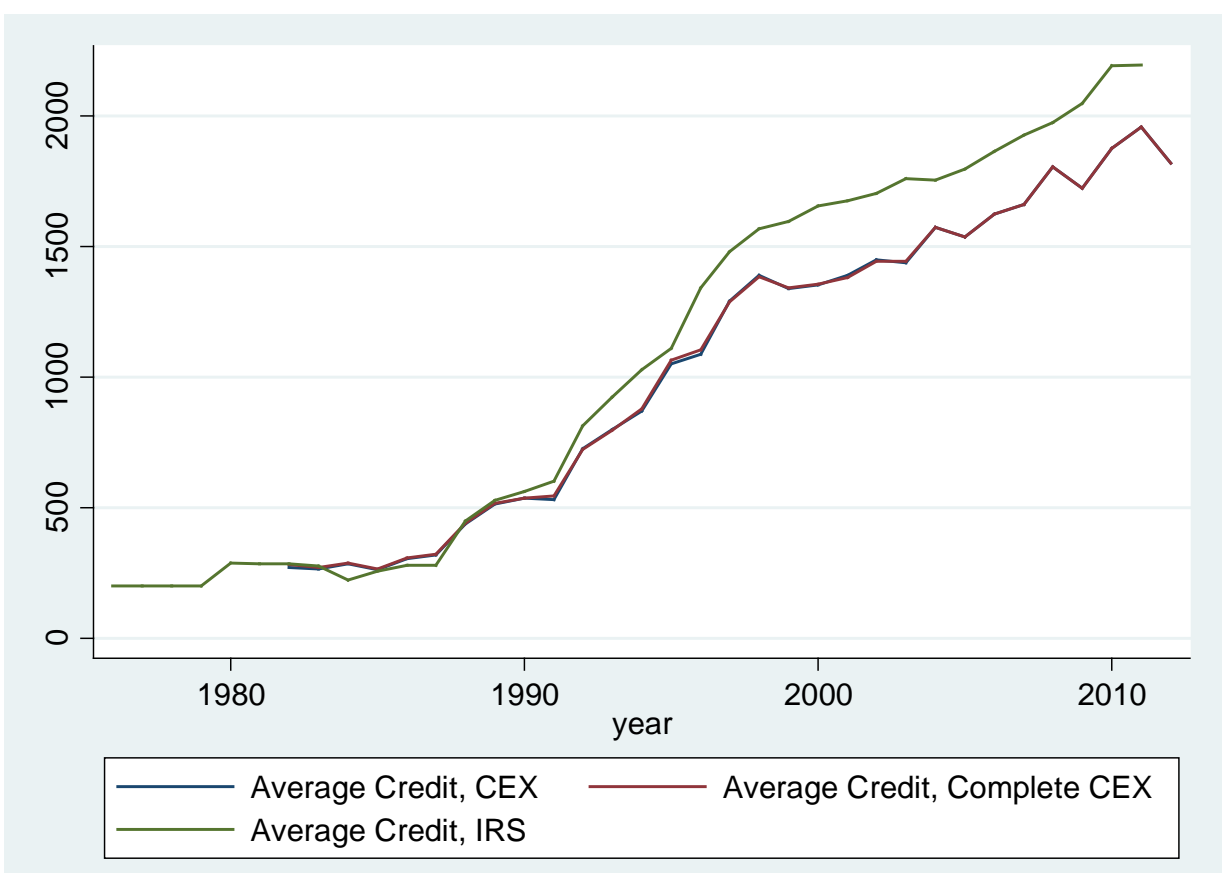

Note: Authors' tabulations based on BLS, Various Years and IRS, Various Years. 
Figure A3: Number of Beneficiaries, IRS Returns vs. CEX Consumer Units

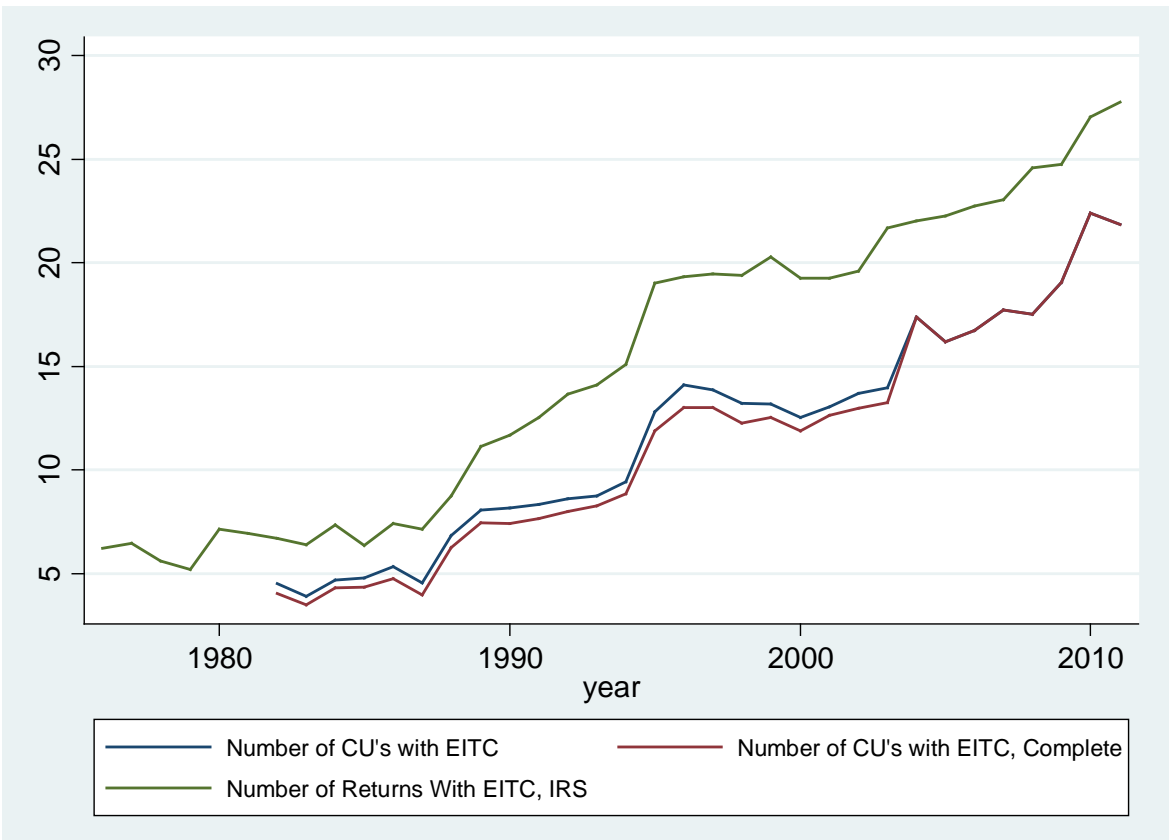

Note: Authors' tabulations based on BLS, Various Years and IRS, Various Years.

Figure A4: Number of Beneficiaries, IRS Tax Units, CEX Consumer Units and Tax Units

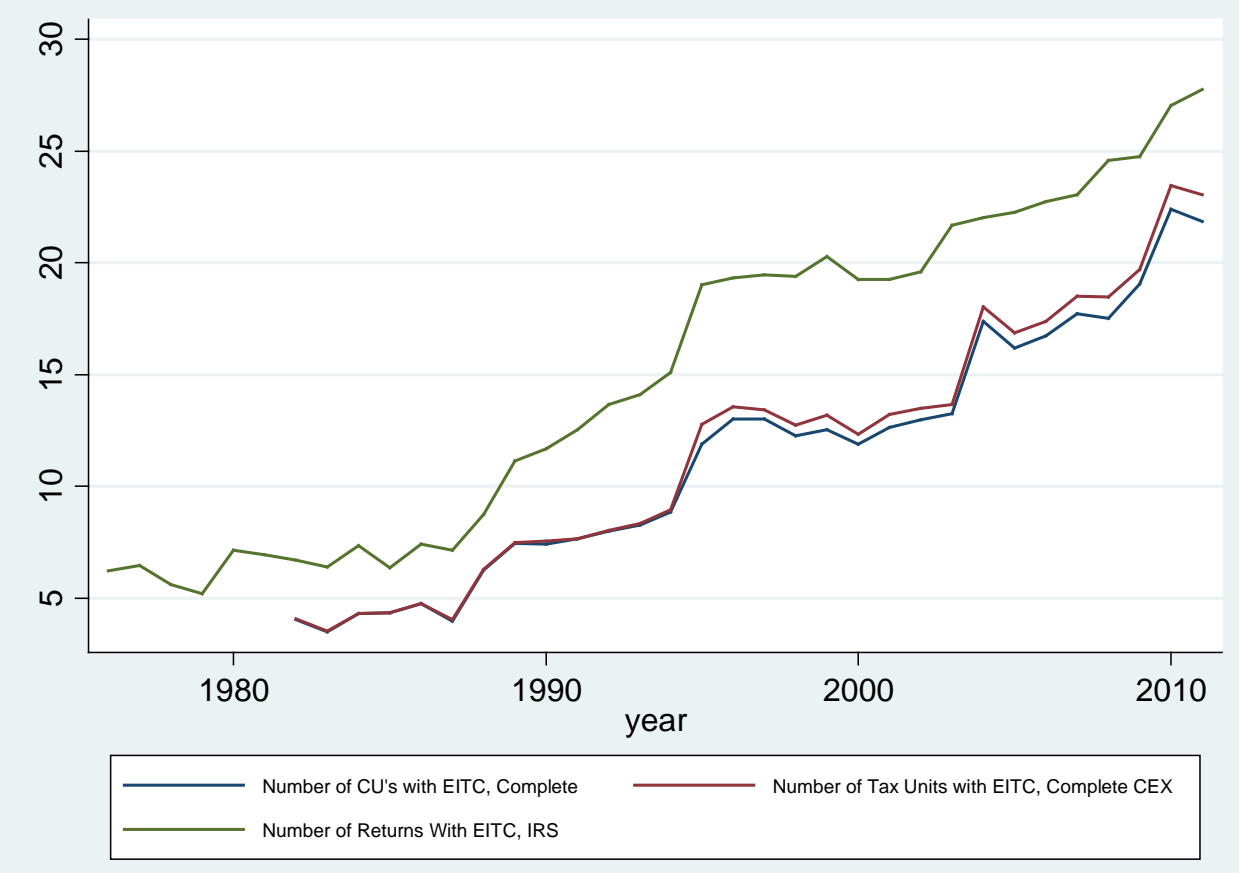

Note: Authors' tabulations based on BLS, Various Years and IRS, Various Years. 
A5: Median Household Pre-tax Income, Census vs. CEX

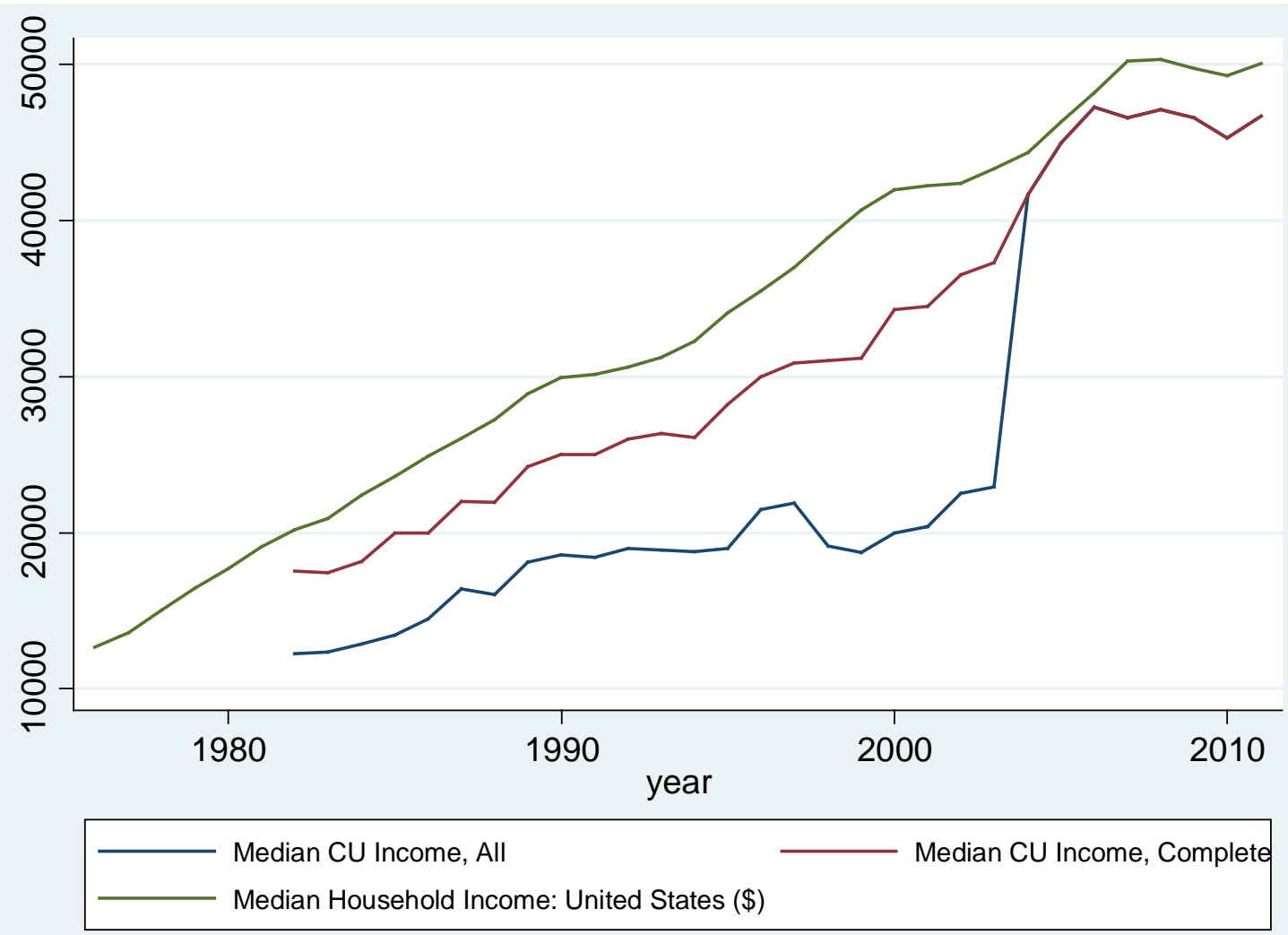

Note: Authors' tabulations based on BLS, Various Years and data from the US Bureau of the Census, via Haver Analytics. 


\section{Working Paper Series}

A series of research studies on regional economic issues relating to the Seventh Federal Reserve District, and on financial and economic topics.

Comment on "Letting Different Views about Business Cycles Compete"

WP-10-01

Jonas D.M. Fisher

Macroeconomic Implications of Agglomeration

WP-10-02

Morris A. Davis, Jonas D.M. Fisher and Toni M. Whited

Accounting for non-annuitization

WP-10-03

Svetlana Pashchenko

Robustness and Macroeconomic Policy

WP-10-04

Gadi Barlevy

Benefits of Relationship Banking: Evidence from Consumer Credit Markets

WP-10-05

Sumit Agarwal, Souphala Chomsisengphet, Chunlin Liu, and Nicholas S. Souleles

The Effect of Sales Tax Holidays on Household Consumption Patterns

WP-10-06

Nathan Marwell and Leslie McGranahan

Gathering Insights on the Forest from the Trees: A New Metric for Financial Conditions

WP-10-07

Scott Brave and R. Andrew Butters

Identification of Models of the Labor Market

WP-10-08

Eric French and Christopher Taber

Public Pensions and Labor Supply Over the Life Cycle

WP-10-09

Eric French and John Jones

Explaining Asset Pricing Puzzles Associated with the 1987 Market Crash

WP-10-10

Luca Benzoni, Pierre Collin-Dufresne, and Robert S. Goldstein

Prenatal Sex Selection and Girls’ Well-Being: Evidence from India

WP-10-11

Luojia Hu and Analía Schlosser

Mortgage Choices and Housing Speculation

WP-10-12

Gadi Barlevy and Jonas D.M. Fisher

Did Adhering to the Gold Standard Reduce the Cost of Capital?

WP-10-13

Ron Alquist and Benjamin Chabot

Introduction to the Macroeconomic Dynamics:

Special issues on money, credit, and liquidity

WP-10-14

Ed Nosal, Christopher Waller, and Randall Wright

Summer Workshop on Money, Banking, Payments and Finance: An Overview

WP-10-15

Ed Nosal and Randall Wright 


\section{Working Paper Series (continued)}

Complex Mortgages

WP-10-17

Gene Amromin, Jennifer Huang, Clemens Sialm, and Edward Zhong

WP-10-18

The Role of Housing in Labor Reallocation

Morris Davis, Jonas Fisher, and Marcelo Veracierto

Why Do Banks Reward their Customers to Use their Credit Cards?

WP-10-19

Sumit Agarwal, Sujit Chakravorti, and Anna Lunn

The impact of the originate-to-distribute model on banks

before and during the financial crisis

WP-10-20

Richard J. Rosen

Simple Markov-Perfect Industry Dynamics

WP-10-21

Jaap H. Abbring, Jeffrey R. Campbell, and Nan Yang

Commodity Money with Frequent Search

WP-10-22

Ezra Oberfield and Nicholas Trachter

Corporate Average Fuel Economy Standards and the Market for New Vehicles Thomas Klier and Joshua Linn

WP-11-01

The Role of Securitization in Mortgage Renegotiation

WP-11-02

Sumit Agarwal, Gene Amromin, Itzhak Ben-David, Souphala Chomsisengphet, and Douglas D. Evanoff

Market-Based Loss Mitigation Practices for Troubled Mortgages

Following the Financial Crisis

WP-11-03

Sumit Agarwal, Gene Amromin, Itzhak Ben-David, Souphala Chomsisengphet, and Douglas D. Evanoff

Federal Reserve Policies and Financial Market Conditions During the Crisis

WP-11-04

Scott A. Brave and Hesna Genay

The Financial Labor Supply Accelerator

WP-11-05

Jeffrey R. Campbell and Zvi Hercowitz

Survival and long-run dynamics with heterogeneous beliefs under recursive preferences

WP-11-06

Jaroslav Borovička

A Leverage-based Model of Speculative Bubbles (Revised)

WP-11-07

Gadi Barlevy

Estimation of Panel Data Regression Models with Two-Sided Censoring or Truncation

WP-11-08

Sule Alan, Bo E. Honoré, Luojia Hu, and Søren Leth-Petersen

Fertility Transitions Along the Extensive and Intensive Margins

WP-11-09

Daniel Aaronson, Fabian Lange, and Bhashkar Mazumder

Black-White Differences in Intergenerational Economic Mobility in the US

WP-11-10

Bhashkar Mazumder 


\section{Working Paper Series (continued)}

Can Standard Preferences Explain the Prices of Out-of-the-Money S\&P 500 Put Options?

Luca Benzoni, Pierre Collin-Dufresne, and Robert S. Goldstein

WP-11-11

Business Networks, Production Chains, and Productivity:

A Theory of Input-Output Architecture

WP-11-12

Ezra Oberfield

Equilibrium Bank Runs Revisited

WP-11-13

Ed Nosal

Are Covered Bonds a Substitute for Mortgage-Backed Securities?

Santiago Carbó-Valverde, Richard J. Rosen, and Francisco Rodríguez-Fernández

WP-11-14

The Cost of Banking Panics in an Age before "Too Big to Fail"

WP-11-15

Benjamin Chabot

Import Protection, Business Cycles, and Exchange Rates:

Evidence from the Great Recession

WP-11-16

Chad P. Bown and Meredith A. Crowley

Examining Macroeconomic Models through the Lens of Asset Pricing

WP-12-01

Jaroslav Borovička and Lars Peter Hansen

The Chicago Fed DSGE Model

Scott A. Brave, Jeffrey R. Campbell, Jonas D.M. Fisher, and Alejandro Justiniano

WP-12-02

Macroeconomic Effects of Federal Reserve Forward Guidance

Jeffrey R. Campbell, Charles L. Evans, Jonas D.M. Fisher, and Alejandro Justiniano

WP-12-03

Modeling Credit Contagion via the Updating of Fragile Beliefs

WP-12-04

Luca Benzoni, Pierre Collin-Dufresne, Robert S. Goldstein, and Jean Helwege

Signaling Effects of Monetary Policy

WP-12-05

Leonardo Melosi

Empirical Research on Sovereign Debt and Default

WP-12-06

Michael Tomz and Mark L. J. Wright

Credit Risk and Disaster Risk

WP-12-07

François Gourio

From the Horse's Mouth: How do Investor Expectations of Risk and Return

Vary with Economic Conditions?

WP-12-08

Gene Amromin and Steven A. Sharpe

Using Vehicle Taxes To Reduce Carbon Dioxide Emissions Rates of

New Passenger Vehicles: Evidence from France, Germany, and Sweden

WP-12-09

Thomas Klier and Joshua Linn

Spending Responses to State Sales Tax Holidays

WP-12-10

Sumit Agarwal and Leslie McGranahan 


\section{Working Paper Series (continued)}

Micro Data and Macro Technology

WP-12-11

Ezra Oberfield and Devesh Raval

The Effect of Disability Insurance Receipt on Labor Supply: A Dynamic Analysis

WP-12-12

Eric French and Jae Song

Medicaid Insurance in Old Age

WP-12-13

Mariacristina De Nardi, Eric French, and John Bailey Jones

WP-12-14

Fetal Origins and Parental Responses

(1)

Repos, Fire Sales, and Bankruptcy Policy

WP-12-15

Gaetano Antinolfi, Francesca Carapella, Charles Kahn, Antoine Martin,

David Mills, and Ed Nosal

Speculative Runs on Interest Rate Pegs

The Frictionless Case

WP-12-16

Marco Bassetto and Christopher Phelan

Institutions, the Cost of Capital, and Long-Run Economic Growth:

Evidence from the 19th Century Capital Market

WP-12-17

Ron Alquist and Ben Chabot

Emerging Economies, Trade Policy, and Macroeconomic Shocks

Chad P. Bown and Meredith A. Crowley

WP-12-18

The Urban Density Premium across Establishments

WP-13-01

R. Jason Faberman and Matthew Freedman

Why Do Borrowers Make Mortgage Refinancing Mistakes?

WP-13-02

Sumit Agarwal, Richard J. Rosen, and Vincent Yao

Bank Panics, Government Guarantees, and the Long-Run Size of the Financial Sector:

Evidence from Free-Banking America

WP-13-03

Benjamin Chabot and Charles C. Moul

Fiscal Consequences of Paying Interest on Reserves

WP-13-04

Marco Bassetto and Todd Messer

Properties of the Vacancy Statistic in the Discrete Circle Covering Problem Gadi Barlevy and H. N. Nagaraja

WP-13-05

Credit Crunches and Credit Allocation in a Model of Entrepreneurship

WP-13-06

Marco Bassetto, Marco Cagetti, and Mariacristina De Nardi 


\section{Working Paper Series (continued)}

Financial Incentives and Educational Investment:

The Impact of Performance-Based Scholarships on Student Time Use

WP-13-07

Lisa Barrow and Cecilia Elena Rouse

The Global Welfare Impact of China: Trade Integration and Technological Change

WP-13-08

Julian di Giovanni, Andrei A. Levchenko, and Jing Zhang

Structural Change in an Open Economy

WP-13-09

Timothy Uy, Kei-Mu Yi, and Jing Zhang

The Global Labor Market Impact of Emerging Giants: a Quantitative Assessment

WP-13-10

Andrei A. Levchenko and Jing Zhang

Size-Dependent Regulations, Firm Size Distribution, and Reallocation

WP-13-11

François Gourio and Nicolas Roys

Modeling the Evolution of Expectations and Uncertainty in General Equilibrium

WP-13-12

Francesco Bianchi and Leonardo Melosi

Rushing into American Dream? House Prices, Timing of Homeownership, and Adjustment of Consumer Credit

WP-13-13

Sumit Agarwal, Luojia Hu, and Xing Huang

The Earned Income Tax Credit and Food Consumption Patterns

WP-13-14

Leslie McGranahan and Diane W. Schanzenbach 